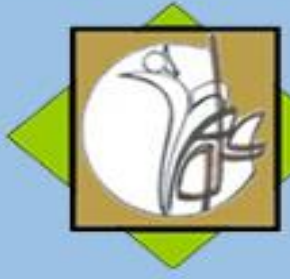

\author{
Research Article
}

\title{
Evaluation of Performance of Isfahan Municipality Cultural and Social Sports Organization Based on CIPP Model with Citizenship Sports Approach
}

\author{
Ali Halajian ${ }^{1}$ 'Mina Mostahfizian² ‘Hamid Reza Mirsafian, Hamid Zahedi \\ 1. Ali Halajian, (Ph. D Student) Islamic Azad University, Najafabad Branch, Najafabad, Iran. \\ 2. Mina Mostahfizian, (Ph. D) Islamic Azad University, Najafabad Branch, Najafabad, Iran. \\ 3. Hamid Reza Mirsafian, (Ph. D) University of Isfahan, Isfahan, Iran. \\ 4. Hamid Zahedi, (Ph. D) Islamic Azad University, Najafabad Branch, Najafabad, Iran
}

\section{ARTICLE INFO \\ Received February 2020 \\ Accepted April 2020 \\ KEYWORDS: \\ Evaluation Performance, Sport Organization, CIPP Model, Citizenship Sport}

\section{CITE:}

Halajian, Mostahfizian, Mirsafian, Zahedi, Evaluation of performance of Isfahan Municipality Cultural and Social Sports Organization based on CIPP model with citizenship sports approach, Research in Sport Management \& Motor Behavior, 2020: 10(20): 203-227

\section{ABSTRACT}

The purpose of the present study was to evaluate the performance of Isfahan Municipality Cultural and Social Sports Organization based on the Clpp model with the approach of citizenship sports. The research method was descriptive in nature and applied in terms of purpose. In the qualitative stage of the research, first the preliminary questions of the interview were created by studying the sources related to the research, collecting information and reviewing the research.The interviewees at this stage were experts in the field of civic sports who were purposefully selected.Then, Delphi method was used in four stages to correct and improve the interview questions. In the quantitative stage of the research, the questions of the questionnaire were extracted after evaluating the themes, in the form of 94 questions, and were implemented among 113 citizen sports experts. The results showed that all four dimensions of context, input, output and process in the evaluation of the performance of this organization are higher than the average level, but need to be improved and increased. Also, evaluation and feedback on the developed programs is necessary both during and after the implementation of the program, because performance evaluation was relatively effective in achieving the goals of this program. 


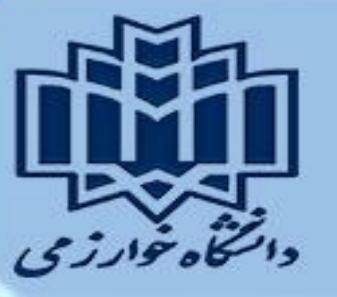

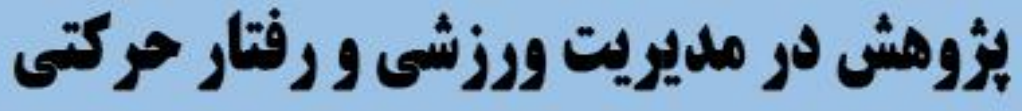

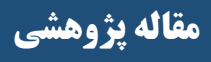

\section{ارزيابى عملكرد سازمان فر هنكى اجتماعى ورزشى شهردارى اصفهان بر اساس التوى سيب با رويكرد ورزش شهروندى}

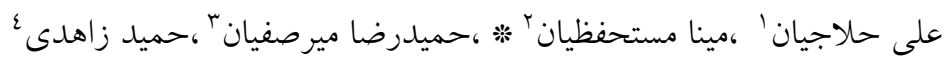

ا. دانشجوى دكترى مديريت ورزشى، كروه تربيت بلدى و علوم ورزشى، واحد نجف آباد، دانشكاه آزاد اسلامى، نجف آباد، ايران.

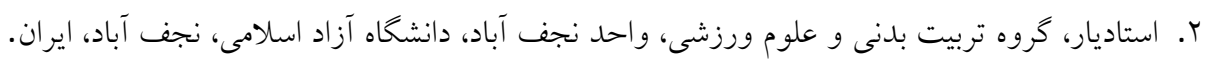

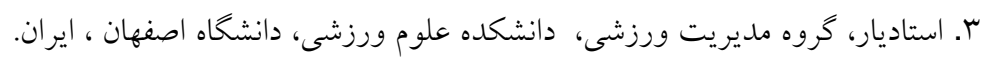

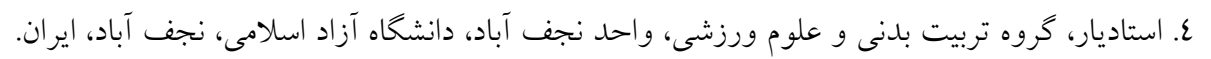

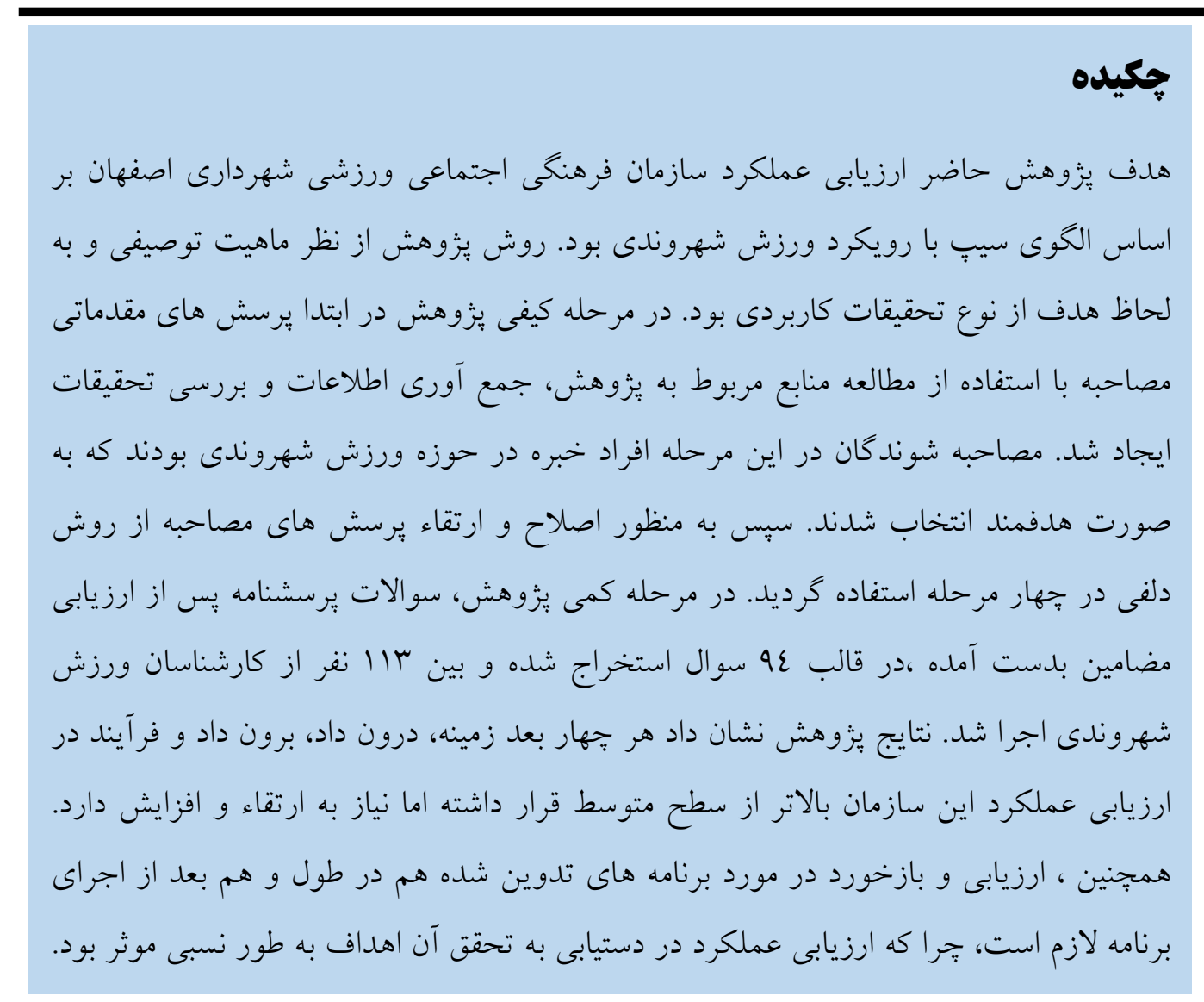

اطلاعات مقاله:

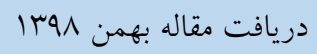

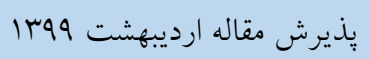

*ونويسنده مسئول:

dr.mostahfezian@gmail.com

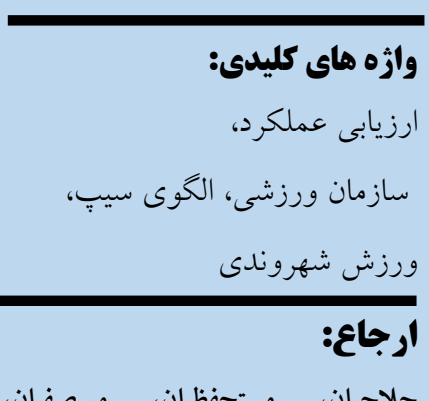

حلاجيان، مستحفظيان، ميرصفيان، زاهدى. ارزيابى عملكرد سازمان فرهنگى اجتماعى ورزشى شهردارى اصفهان بر اساس الخوى سيبٍ با رويكرد ورزش

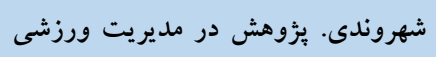

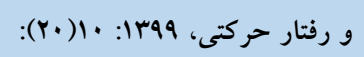

$r \cdot r-Y r V$ 


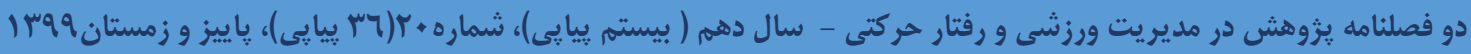

مقلدمه

ورزش نوعى بازى سـازمان يافته و هدفمند اسـت كه در آن حركت ها به منظور تقويت قواى جسـمانى، افزايش روحيه و كسـب مهارت اجرا مى شـود (1). اهداف تربيت بلنى و ورزش با تجارب و علايق افراد در ارتباطند و تعيين كننده مقاصد و جهت برنامه ها هستند و با توجه به اهميت و تو سعه حيطه علم تربيت بلدنى و ورزش اهداف آن محدود به رده هاى جمعيتى خاصسى نيسـت، بلكه به تمام رده هاى جمعيتى كسـترش يافته اسـت (Y). بنابر اين نقش ورزش و فعاليت بدنى به عنوان راهبردى كه توانيى بالقوه اى در يارى رســاندن به اهداف سـلامتى، اجتماعى و اقتصـادى دارد، بسـيار حائز اهميت مى باشـــ (Y). ورزش همشانى اهدافى جون حفظ سـلامت، تعميم بهداشـت، رشـد و تقويت قواى جسمى، آمادكى براى فعاليت هاى دفاعى، كسب شادابى و ذشاط و كسب موفقيت شغلى و حرفه ایى را دنبال مى كند. اين اهداف با تغييرات اندكى در نزد اكثريت جوامع بشـرى ترويج مى شـود و برحسـب ضـرورت بر يك يا جند هدف تأكيد بي شترى به عمل مى آيد. با صنعتى شدن جوامع و افزايش اوقات فراغت، ورزش همخانى با اهداف سركرمى و ايجاد نشـاط و سـلامتى دنبال مى شـود (ع). با توجه به اهميت و نقش تحرك و فعاليت هاى بلنى در زندكى روزمره و سـالامت افراد جامعه، بايد محيطى را فراهم سـاخت و خدماتى را ارائه داد كه افراد بتوانند سـاعاتى را با علاقه و تمايل وافر و به دور از مسائل اجتماعى و خانو ادگىى به ورزش و فعاليت هاى بدنى بيردازند (0). تو سعهُ ورزش همگانى زمينه را براى رشـــ ورزش قهرمانى فراهم مى كند و الزام اسـتـ ورزش همخانى بيش از ورزش قهرمانى توســعه يابد (7). ورزش همشانى در واقع كوششى جهت رواج دادن ورزش بين تمام اقشار جامعه بوده و داراى اثرات بهداشتى، اجتماعى و فرهنكى مى با شد. امروزه حدود Or ورزش در جهان، به عنوان ورزش همخانى شناخته شده و طيفى از دويدن هاى آرام تا بازى هاى المييك را شامل مى شوند. برخى ديخر از صاحب نظران، ورزش همخانى را ورزشى مى دانند كه بطور

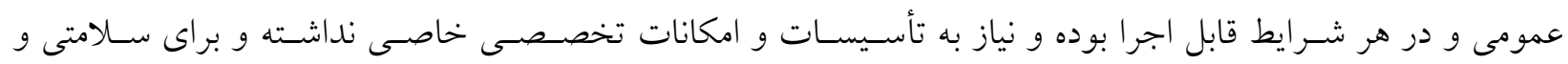
كذراندن اوقات فراغت به اجرا در مى آيد (V). شهردارى به عنوان يكى از سازمانهاى مهمى كه خدمات وسيعى در زمينهاى مختلف به شهروندان ارائه مىدهد،

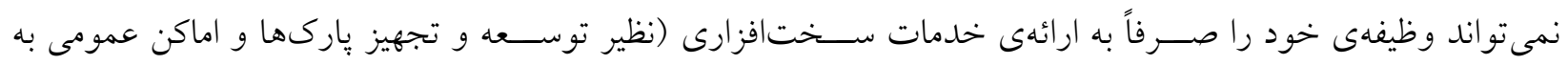
و سايل ورز شى) محدود كند. اين نوع خدمات به رغم ضرورتى كه دارند نه تنها شرط لازم براى تو سعهى ورزشهاى

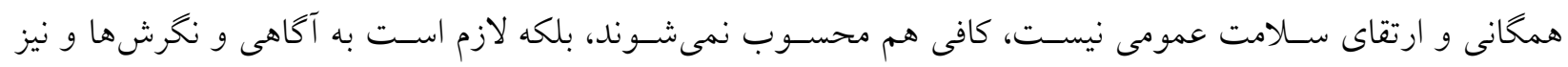
نيازهاى شهروندان در زمينهى ورزش همخانى توجه شود، جه، بـ سا امكانات بـ سيار ارز شمندى كه به سبب يايين بودن سطح آكاهى مردم يا نامناسب بودن نخرشهاى آنان و يا عدم تناسب با نيازهاى ذهنى شهروندان، اثربخشى لازم را نداشته باشند. اين بخش از حقيقت ورزشهاى همخانى امرى نيست كه بتوان با تو سل به تجربههاى شخصى يا حدس و گمان

به بوتهى آزمايش و خطا سيرد، لذا انجام يُزوهشهاى هوشمند در اين زمينه امرى ضرورى و اجتنابنايذير است (N). سـاليان زيادى در حوزه ورزش شـهروندى مديران مختلف به اصــطلاح برنامه هاى عملياتى درعرصسه ورزش 


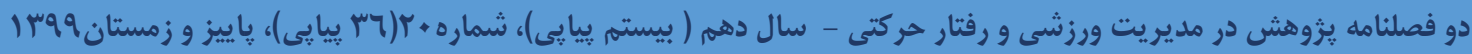

شهروندى اصفهان پِا گذاشته، وليكن تاكنون به خاطر صرفا" ارائه گزارش هاى كمى، كيفيت انجام برنامه ها بسيار پِيين بوده و هست، به همين دليل اين يزوهش مى تواند كام هاى استوارى در خصوص الكو سازى براى مديران و متخصصين

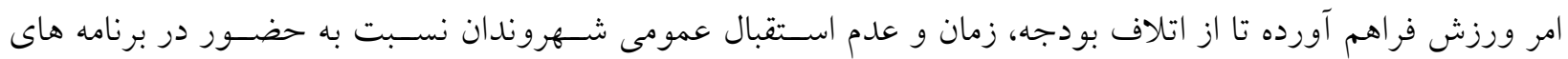
ورزش شهروندى جلو گيرى به عمل آورد. سازمان هاى ورز شى نيازمند نوعى نظام ارزيابى عملكرد هـ ستند كه قابليت اثر بخشى درى سيا ست كذارى ها و راهبردهاى كلان را داشـته باشــــ. وجود نظام ارزيابى اثربخش كه با توجه به تنوع ماموريت، راهبرد، سـاختار و نيروى اذسانى قادر با شد تا برنامه ها را منطبق بر نيازمندى هاى داذشى و با دقت قابل قبولى ارزيابى نمايد، بـسيار حائز اهميت اسـت. به همين منظور ادبيات موضـوع و جامعه آمارى يزوهش حاضـر، مورد مطالعه قرار كرفت و نهايتا به شــاسـايى

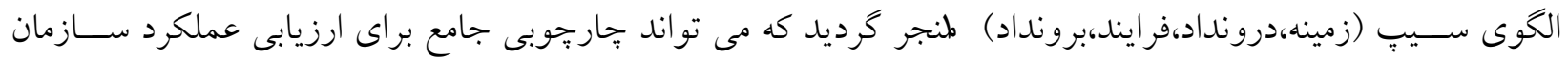
فرهنگى اجتماعى ورز شى شهردارى اصفهان ايجاد نمايد و اطلاعات صحيح و قابل اتكايى را براى اتخاذ تصميم هاى راهبردى مديران حوزه ورزش فراهم آورد. در اين راسـتا در يُزوهش حاضــر اعتبار الكوى سـيبٍ و ميزان تاثير كذارى

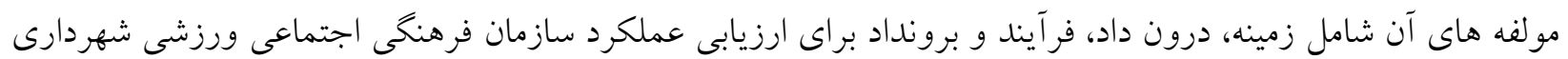
اصفهان مورد برر سى قرار كرفت. به نظر مى ر سد با استفاده از نتايج تحقيق حاضر، برنامه ريزان و مسئولين شهردارى اصفهان مى توانند به رفع برخى از مشكلات و موانع حوزه ورزش شهروندى اقدام نمايند و با اين كار به افزايش كارآيى و اثربخشى آنان كمى كنند. به همين دليل انجام تحقيقى كاربردى كه بتواند عملكرد سازمان فرهنكى اجتماعى ورز شى شهردارى اصفهان را به طور دقيق تر مورد ارزيابى قرار دهد، ضرورى به نظر مى رسيد. اسـتفاده مناسـب از الكوهاى ارزيابى براى برقرارى ارتباط و مديريت فرآيندهاى تصـميم گيرى در مديريت موثر

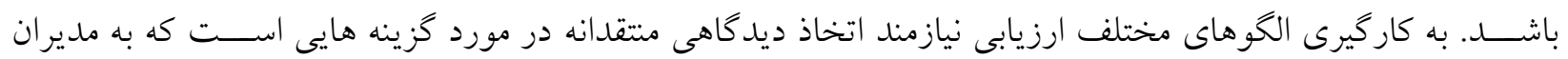
كمك مى كند تا الخوهاى ارزيابى را به منظور بهبود تصـميم كيرى مورد توجه قرار دهند. هدف الكوى ارزيابى تسـهيل

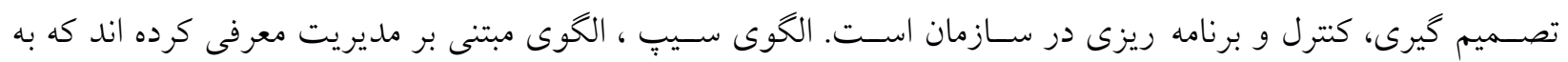
مديران و سرير ستان در ت صميم گيرى كمك مى كند. در الكوى ارزيابى سيبٍ نقش ارز شيابان، تدارك اطلاعات براى

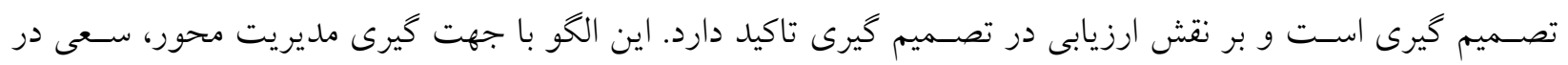
فر اهم كردن اطلاعات صريح و معتبر براى تصميم كيرى در موقعيت هاى مختلف مديريتى دارد. داشتن اطلاعاتى با اين

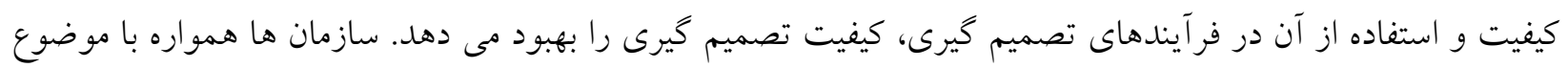
ارزيابى به عنوان يك مساله جالش برانخيز روبرو بوده اند. استفاده از الخُى سيبٍ را براى شناسايى نقاط قوت و ضعف فرآيندهاى ،توصيه شده است و نتايج حاصل از آن را در بهبود عملكردها موثر بوده است (9). 


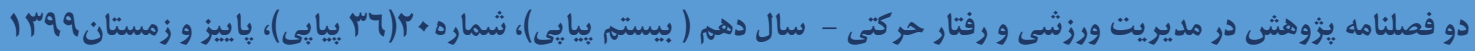

كان، مندل و وينبرى (ع إr) اشاره بر اين داشتند كه الخوى ارزيابى سيبٍ يك ساختارى را براى بيخيرى اجزاى

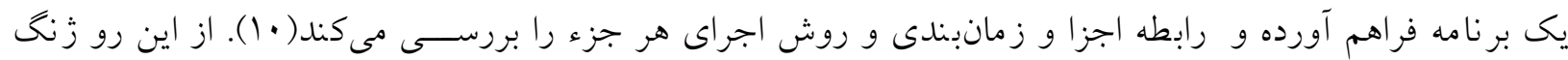

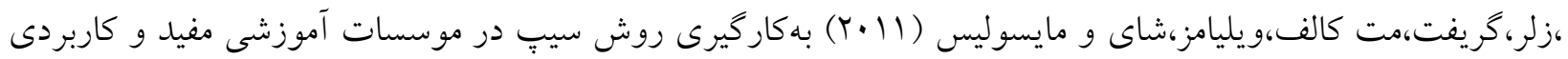

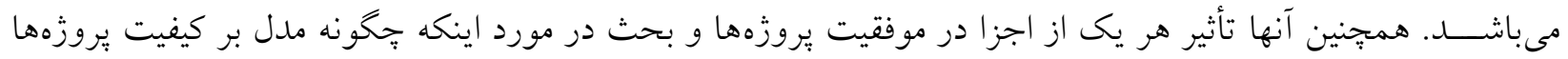

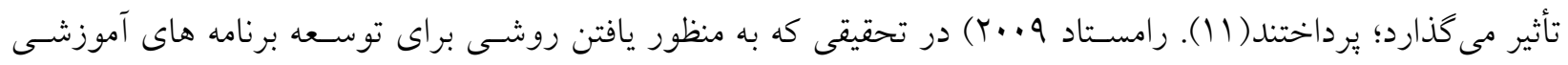

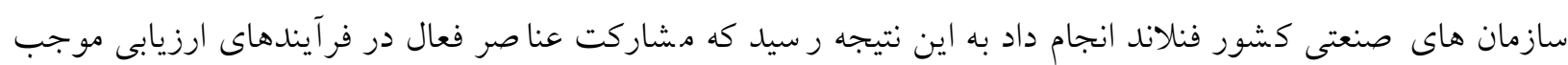
بهبود فعاليت ها و موفقيت برنامه ها مى شود. به زعم وى الكوى سيب اين امكان را در اختيار قرار مى دهد(Y) (I). مطالعات متعدد در حوزه ارزيابى جامع عملكرد بر اسـاس الكوى سـيقٍ انجام شــده كه مى توان به يزوهش هاى

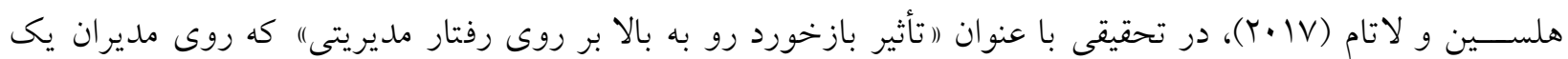

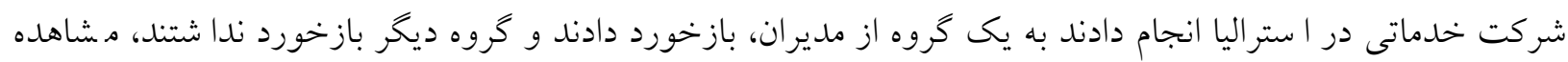

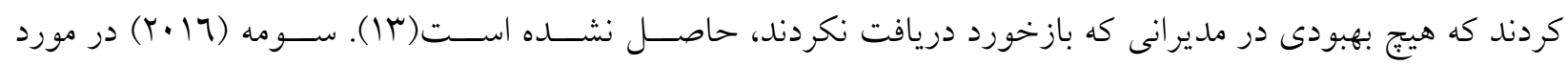
اثربخ شى ارزيابى اثربخ شى برنامه مطالعه درس از ديدگاه معلمان برا ساس الكوى سيب در ا ستان تهران، به اين نتيجه رسيدند كه اين طرح در ابعاد زمينه، درون داد، فر آيند و برون داد داراى كيفيت مطلوبى مىباشد(ع (). هج ياها،جان تان و

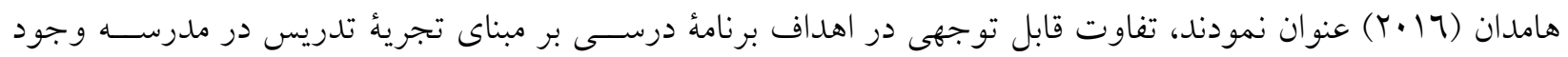
نداشــــ در مورد بعد ورودى در ارزيابى و اعتبارســنجى، دانش محتوايى، انتخاب منابع تدريس و ياد گيرى و مهارت

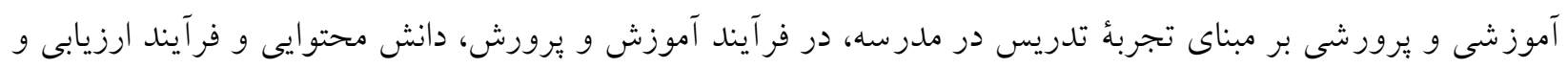
اعتبارسـنجى بر مبناى تجربهُ درسـى در مدرسـهـ و در بعد محصــول برنامهُ عملى بر مبناى تجربهُ تدريس در مدرسـهـ

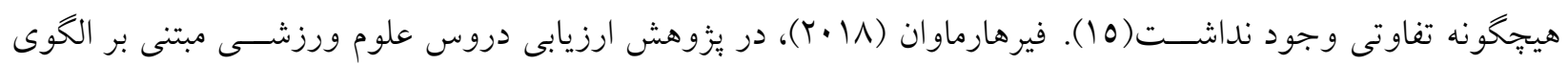
سيبٍ در برنامه تحصيلى دانشخاه كبومن مشاهده نمود، سه عامل اصلى براى ضعف دروس علوم ورزشى وجود دارد: ا- ناكار آمدى محتواى در سى r- شيوه هاى تدريس نامنا سب r- عدم كيفيت منا سب برنامه هاى در سى علوم

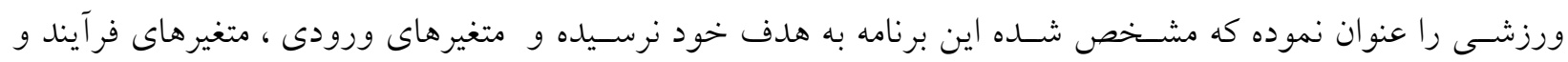
محصول ، به طور متقابل بر موفقيت تدريس براى يك دوره آموزشى تأثير مى كذارد(7 (1). سازمان هاى ورزشى مانند اكثر سازمان ها و نهادهاى ساير حوزه ها براى بقا و دوام در عرصه رقابت جهانى به به بـ سازمانى راهبرد محور تبديل شدند، جرا كه تفكر راهبردى، در جستجوى جرخه هاى زاينده و پاينده براى سازمان است (IV). يزوهش هايى كه در حوزه ارزيابى عملكرد در ورزش انجام شده مى توان به يزوهش موسيوند و همكاران (10) با عنوان ارزيابى دوره هاى ضمن خدمت دبيران تربيت بدنى بر اساس الكوى سيب اشاره بر اين دارد كه نتايج حاكى از آن مطلوبيتى در ابعاد محتوا و فرآيند، زمينه و نتايج مشاهده نشد و مى بايست در هر عزمينه تغييرات اساسى در محتواى آموزشى، بركزارى دوره هاى آموزشى، ارزيابى ساختار آموزشى و بكاركيرى مدرسين متخصص بعمل آيد(1) . بايد توجه 


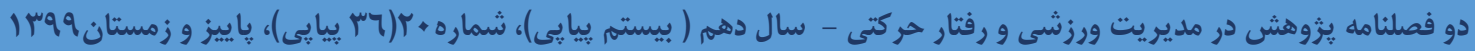

داشت كه منظور از ارزيابى عملكرد، فرآيندى است كه بوسيله آن كاركنان در فواصل معينى و بطور رسمى، مورد ارزيابى قرار مى گيرند.نظىى و همكاران (97 (1) در يزوهش ارزيابى جامع عملكرد حوزه ورزش آموزش و يرورش اصفهان بر اساس الكوى ارزيابى سيٍٍ به اين نتيجه رسيدند كه هر جهار بعد زمينه، درون داد، برون داد و فرآيند در ارزيابى جامع

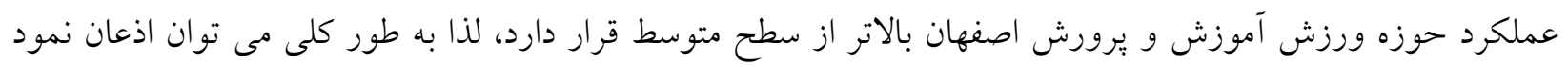

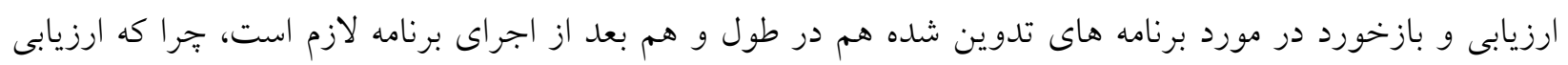

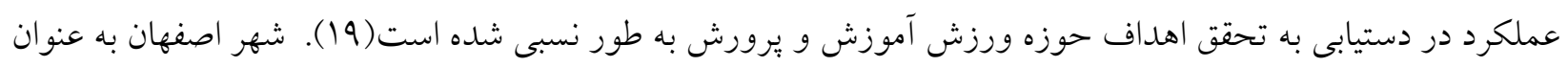
سومين كلان شهر كشور با داشتن پيانزده منطقه و جمعيتى بالغ بر دو ميليون و دويست و جهل هزار نفر (آمارنامه شهر

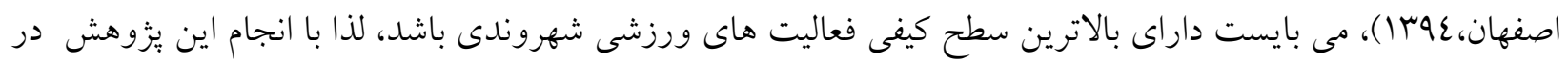
خصوص ارزيابى وضعيت عملكرد سازمان فرهنكى اجتماعى ورزشى شهردارى اصفهان بر اساس الكوى سيبٍ با رويكرد ورزش شهروندى بر آن بوده ، بتوانيم از سليقه هاى غير تخصصى در مديتئ مديت سازمان ورزش اين كلان شهر دور شده و

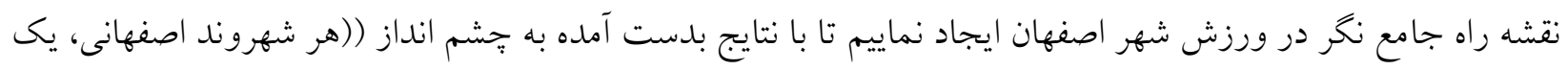
ورزشكار همخانى)) دست بيدا كنيم.

\section{روش شناسى}

با توجه به اينكه در اين يزوهش، يزوهشكر درصدد ارزيابى عملكرد سازمان فرهنكى اجتماعى ورزشى شهردارى اصفهان با توجه به اهداف اين سازمان در حوزه ورزش شهروندى به شرح (احياى فرهنى ورزش يهلو انى و زورخانه ایى ، ارتقاى سطح سلامت و نشاط عمومى شهروندان، توسعه و رونق ورزش شهروندى) بود ، لذا بر اساس اهداف مذكور و با استفاده از الكوى سيبٍ با رويكرد ورزش شهروندى، ارزيابى عملكرد صورت يذيرفت. روش يزوهش حاضر از نظر ماهيت توصيفى است، كه به لحاظ هدف از نوع تحقيقات كاربردى انجام شد. با استفاده از تحليل مضمون حاصل از منابع مرتبط با موضوع و مصاحبه نيمه ساختاريافته با اساتيد و صاحب نظران، ابزار اندازهيرى تدوين و در مرحله كمى،

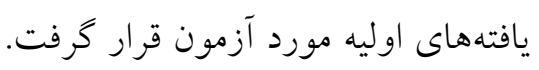

در بخش كيفى تحقيق به منظور تدوين يرسشنامه مرتبط با موضوع يزوهش در ابتدا مصاحبهاى نيمه ساختار يافته

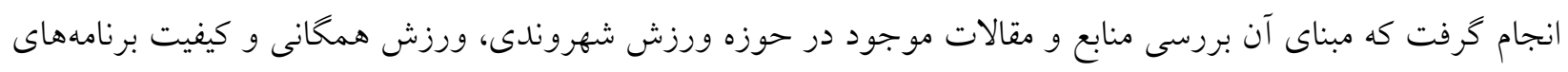
ورز شى بود. محدوده و حيطه مصاحبه بر اساس الكوى سيبٍ (زمينه، درونداد، فرايند، برونداد) تعيين شده و سوالات

مصاحبه نيز در اين جهار حيطه تنظيم شد.

سؤالات دصاحبه بركرفته از ·r سؤال باز ياسخ و به صورت نيمه ساختاريافته بود، مصاحبه ها رودررو و عميق

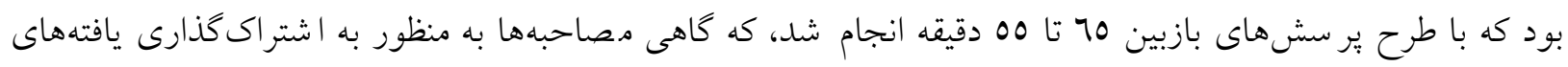
مقدماتى، تكميل، اصلاح و جرح و تعديل دادهها تكرار مى شدند. از مشاركت كنندكان درباره تجاربشان، مشاهداتشان از مصاديق و راهبردها، عوامل بازدارنده و مشكلات و بيامدهاى احتمالى فرايند عملكرد سازمان ورزش شهردارى اصفهان 


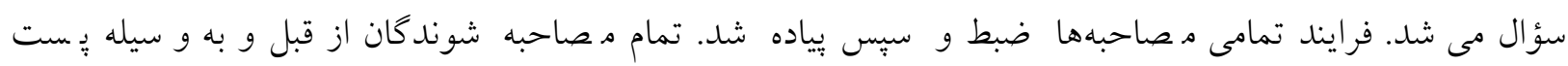
الكترونيكى و اتوماسيون ادارى در جريان هدف و سؤالات مصاحبه قرار گرفته و يس از بيخيرى تلفنى و اعلام موافقت افراد و تعيين مكان و زمان ملاقات، مصاحبه بر گزار شد.

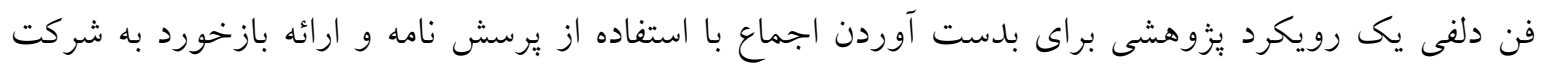

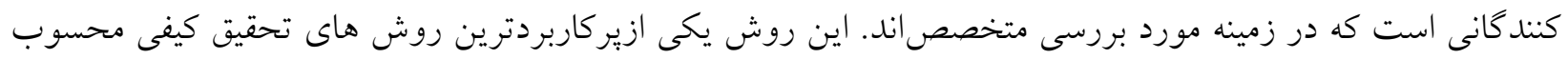

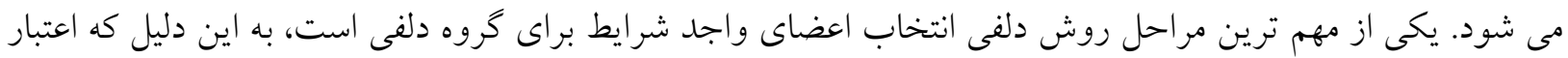

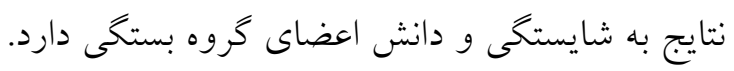
جامعه آمارى اين يزوهش در بخش كيفى شامل كليه افراد خبره در حوزه ورزش شهروندى در شهردارى اصفهان

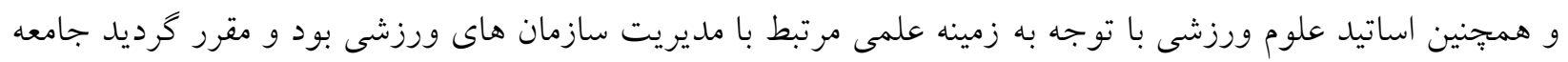

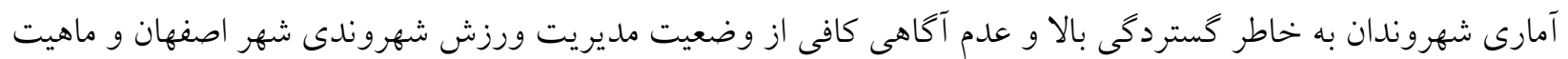

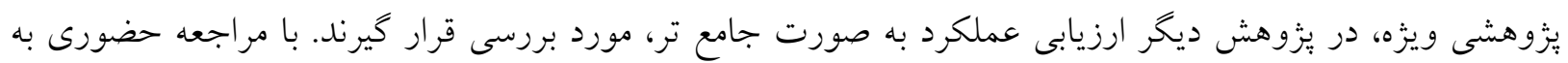

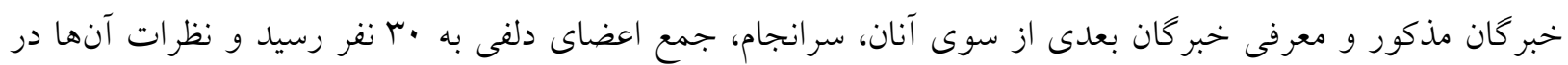

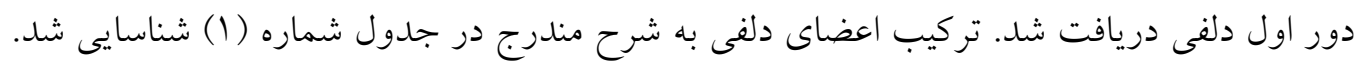

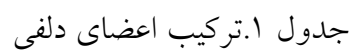

\begin{tabular}{|c|c|c|}
\hline تعداد (نفر) & شرح گروه & كروه \\
\hline 0 & 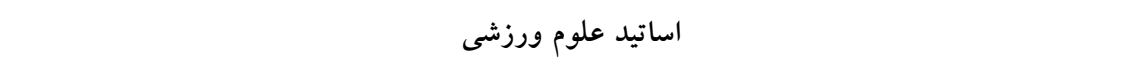 & اول \\
\hline$\wedge$ & مديران ستادى معاونت ورزشى تفريحى سازمان فرهنكى اجتماعى شهردارى اصفهان & 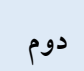 \\
\hline ir & كارشناسان متخصص معاونت ورزشى تفريحى سازمان فرهنگى اجتماعى شهردارى اصفهان & سوم \\
\hline 0 & مسئولين متخصص مراكز ورزشى معاونت ورزشى تفريحى سازمان فرهنگى اجتماعى شهردارى اصفهان & 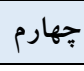 \\
\hline r. & جمع كل & \\
\hline
\end{tabular}

بعد از اجراى دور اول دلفى،به منظور اصلاح و ارتقاء يرسش هاى مصاحبه،از روش دلفى در سه مرحله ديخر

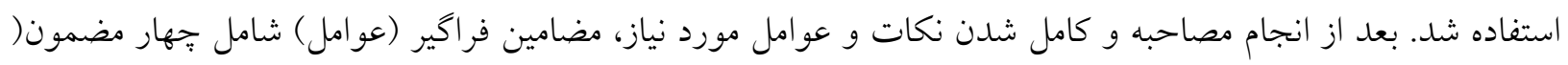

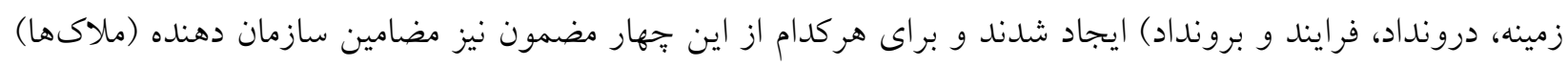

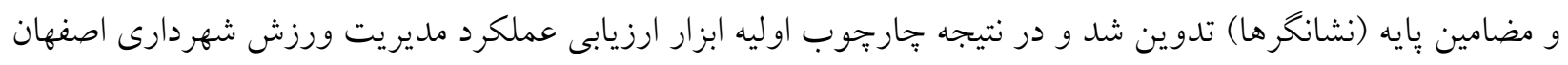

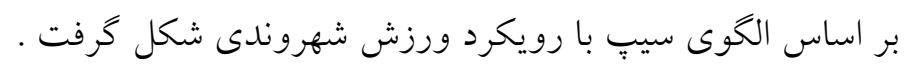

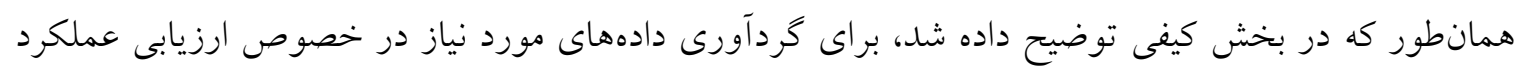

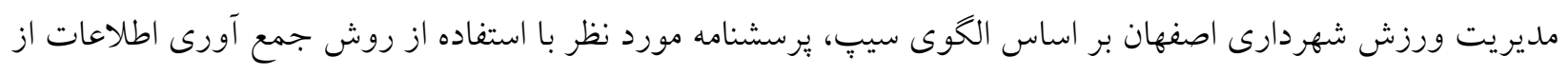

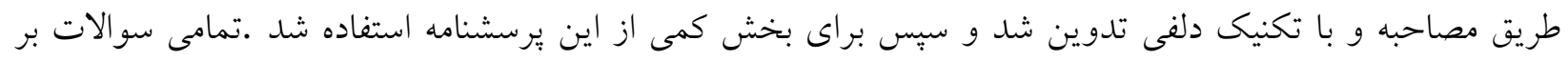

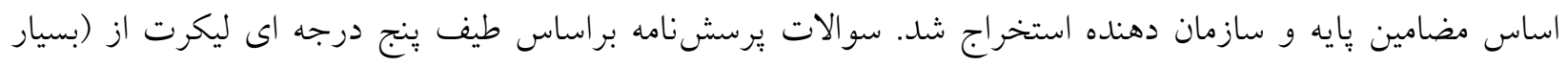

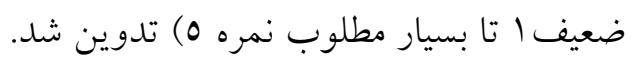




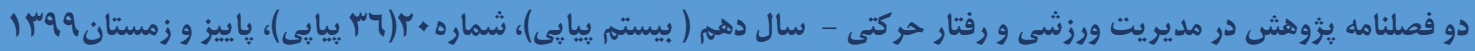

به منظور بررسى روايى يرسشنامه مصاحبه در بخش كيفى از روش روايى محتوايى با استفاده از ضريب نسبى

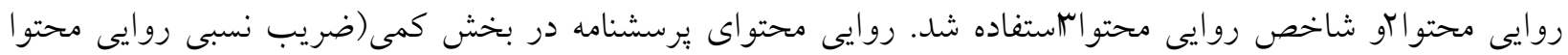

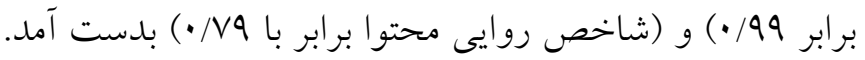

جهت تعيين روايى محتو ايى برسشنامه در بخش كمى، ابتدا با استفاده از منابع و تحقيقات انجام شده و و مصاحبه انجام شده و مشورت با استاد راهنما و مشاور 0 •اسوال كه هر يك از سوالات در يك طيف از (اخيلى ضعيف تا خيلى

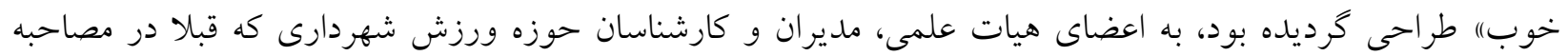

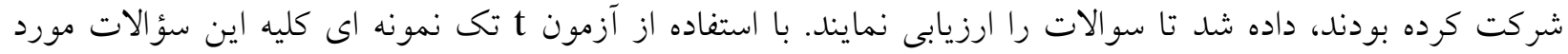
ارزيابى قرار گرفت.

سبس براى به دست آوردن روايى يرسشنامه نهايى در يُزوهش، از دو روش محاسبه همبستخى سؤالات مقياس با نمره

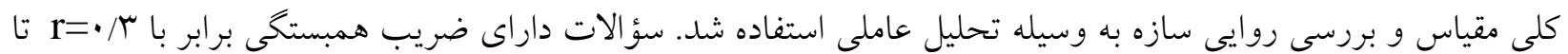

$$
\text { r=•/V بوده و در سطح } 0 \text { • • معنادار بودند. }
$$

روايى سازه با استفاده از تحليل عاملى انجام شد. روايى سازه بيان مى كند نتايج به دست آمده از كاربرد يك ابزار

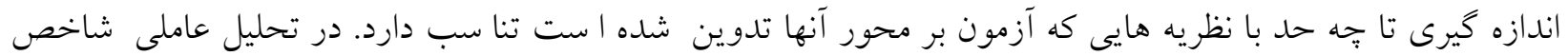
كفايت نمونه كيرى عو آزمون كرويت بارتلت مبراى تاييد ميزان همب ستخى خطى متغيرها و تاييد روايى ا ستفاده مى شود. اكر همبستخى خطى و قوى بين متغيرها وجود داشته باشد، شاخص كفايت نمونه كيرى نزديك به ا خواهد بود. نتيجه

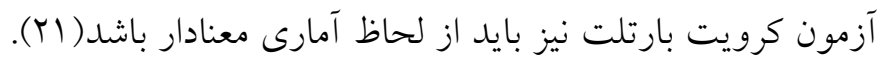

\begin{tabular}{|c|c|c|}
\hline \multicolumn{2}{|c|}{ - Arr } & شاخص كفايت نمونه گيرى \\
\hline $1 \cdot r \sum q / V Y \Lambda$ & مجذور خى & \multirow{2}{*}{ آزمون كرويت بارتلت } \\
\hline$\cdot \cdots$ & سطح معنى دارى & \\
\hline
\end{tabular}

جنانكه در جدول (Y) ديده مى شود، مقدار شاخص كفايت نمونه گيرى برابر با NYY/• است كه بيشتر از V/• است. نشان دهنده اين است كه همبستخى هاى موجود در بين داده ها براى تحليل عاملى مناسب است. همجنين سطح معنادار بودن مشخصه آزمون كرويت بارتلت نيز صفر است كه كوجهتر از 0•/ • است و ذشان مى دهد از لحاظ آمارى معنادار است. بنابراين، بر بايه هر دو ملاكى مىتوان نتيجه گرفت كه اجراى تحليل عاملى براساس ماتريس همبستخى حاصل در

1- Relative coefficient of content validity

2- Content validity index

${ }^{4}$ - Kaiser-Meyer-Olkin (KMO)

5 - Bartlett test of sphericity

https://jrsm.khu.ac.ir/ 


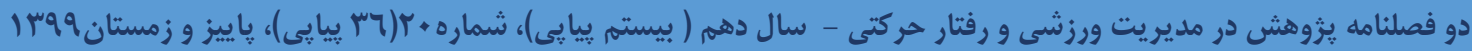

كروه نمونه مورد مطالعه، قابل توجيه بود. خروجى دوم تحليل عاملى اكتشــافى جدول اشــتراكات ناميده مىشــود كه

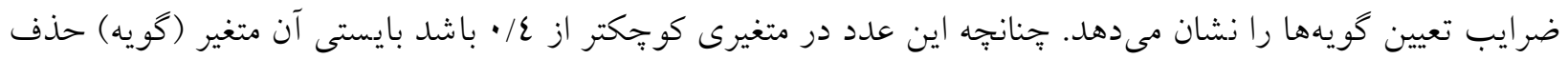
شود و مجدداً تحليل عامل اكتشافى انجام شود. هر جهه مقادير اشتراك استخراجى بزركتر باشد، عاملهاى استخراج شده، متغيرها را بهتر نشان مى دهند (YT). جامعه آمارى بخش كمى اين يزوهش، شـامل 10 نفر اسـاتيد دانشـاه كرايش علوم ورزشسى و مسئولين و كار شناسان حوزه ورزش شهردارى اصفهان جمعا" به تعداد •17 نقر بودند كه به استناد فرمول كوكران و با

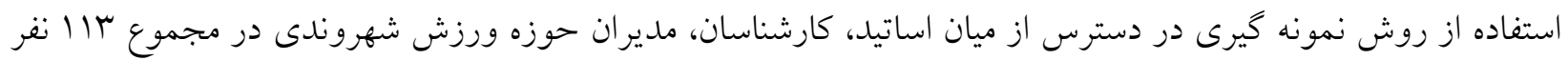
انتخاب شدند. تجزيه و تحليل دادههاى حاصل از ير سمشنامههاى يزوهش با ا ستفاده از نرمافزار آمارى SPSS-23 در دو سطح

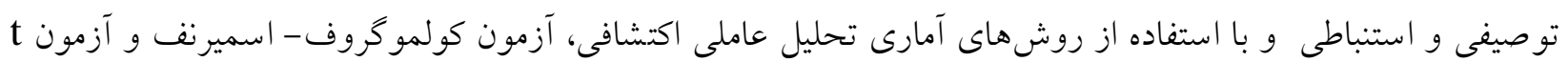
تكى متغيره انجام كرديد.

\section{نتايج}

براى تعيين ميزان اتفاق نظر ميان اعضاى شركت كننده در روش دلفى از ضريب هماهنكى كندال †استفاده شد. ضريب هماهنكى كندال مقياسى براى تعيين درجه هماهنكى و موافقت ميان N شيى يا فرد است. ضريب توافق كندال در دامنه صفر تا يك قرار مى كيرد كه نشان دهنده درجه اجماعى است كه از طريق گروه به دست آمده است (اجماع قوى

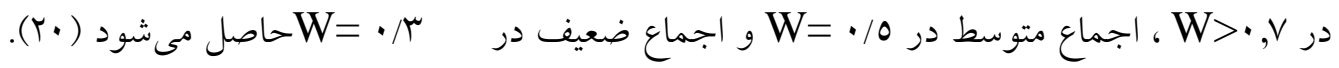
جدول r ميزان اجماع نظر خبر كان با استفاده از ضريب هماهنخى كندال

\begin{tabular}{|c|c|c|c|c|}
\hline سطح معنادارى & آمار كاى دو & ضريب كندال W) & تعداد عامل ها & مضامين \\
\hline .1 .00 & $|\varepsilon| / A \Lambda T$ & $\cdot / V \cdot V$ & 7 & زمينه اى \\
\hline$\cdot / \cdot 71$ & 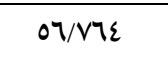 & - /AVO & 7 & درونداد \\
\hline$\cdot / 1 \cdot \varepsilon$ & $00 / 1 V r$ & $\cdot / V \cdot r$ & 0 & فرآيند \\
\hline . /YYE & $r \varepsilon / \varepsilon r q$ & ./V94 & 0 & برونداد \\
\hline
\end{tabular}

نتايج جدول(r)، بيانگر آن است كه مقدار ضريب كندال براى همه عوامل مدنظر بيشتر از V/ • يا بسيار نزديك به آن است كه دلالت بر اجماع قوى خبر كان دارد. سطح معنادارى براى ضريب هماهنكى كندال در همه عوامل نيز بيش از •• • است كه به معناى وجود توافق معنادار بين خبر گان است. بنابراين، مىتوان كفت كه در همين مرحله بين خبر گان اجماع كلى برقرار شده است.

بعد از اجراى دور اول دلفى و به دسـت آوردن نتايج مورد قبول اجماع كلى بين خبر گان در جدول (r) به منظور

\footnotetext{
.1- Kendall Coefficient of Coordination
} 


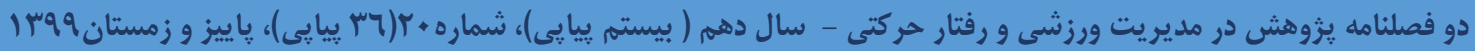

ارزيابى تكى تك مضامين استخراج شده با پايه الكوى سيب، از آزمون t تك نمونهاى استفاده شد و در اين آزمون مقدار

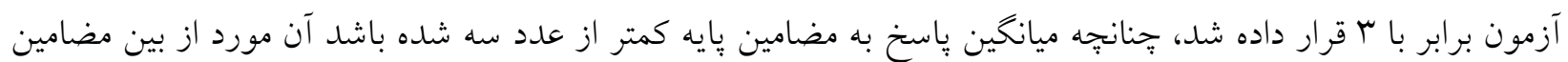
حذف شده.

همانگونه كه نتايج جدول شـماره (ع) نشـان مى دهد، در بخش مضــامين يايه در قالب 0 • 1 مضـمون به عنوان نشانكرهاى ارزشيابى، در بخش مضامين سازمان دهنده در قالب ب T مضمون و ع مضامين فراكير در قالب عوامل زمينه، درون داد، فرايند و برون داد طبقه بندى شدند. درنتيجه جارجوب اوليه ابزار ارزيابى عملكرد مديريت ورزش شهردارى اصفهان بر اساس الخوى سيب شكل گرفت.

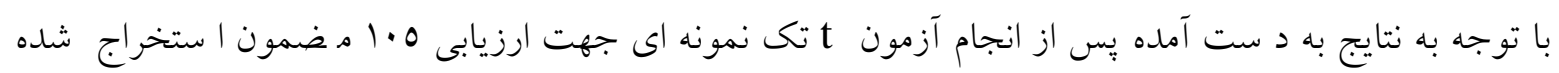
براى تدوين سوالات نهايى برسشنامه يزوهش ، مضامين بايه با شمارههاى 9 (تناسب اهداف با نيازهاى ورزشى جامعه)، 7 (احترام به تفاوتهاى فرهنگى در برنامه هاى ارائه شده در ورزش همخانى)، عץ (تناسب برنامه هاى ورزشى با فرهنگ و نيازهاى مردم در قسمت هاى مختلف شهر)، \^ (تجديدنظر در قوانين و مقررات ورزشى)، عץ (ياسخكويى محتواى

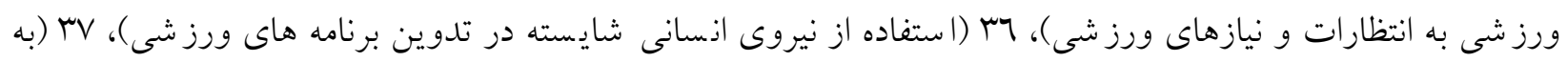
كار گيرى مديران متخصص ورز شى)، عO(تقويت هو شمند سازى در مديريت ورز شى شهردارى)، OV (وجود قوانين و

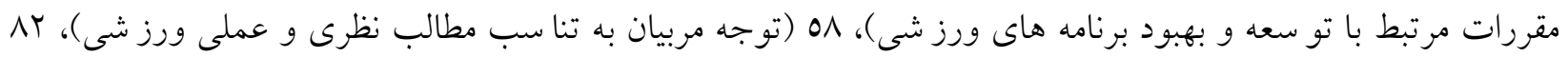
(ميزان تخصص گرايى و شايسته سالارى در ارتباط با برنامه ريزى، اجرا و تو سعه برنامه هاى ورزش شهردارى) و 90 (تقويت نخرش مثبت به ورزش همخانى در بين اقشار مختلف جامعه) با مقدار 1/97 و سطح معنادارى بيشتر از 0 •٪ ،

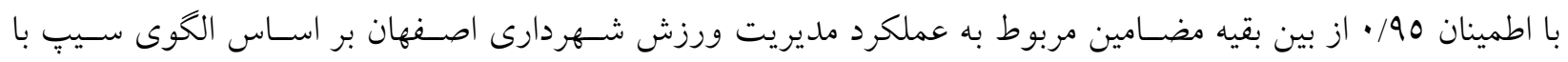
رويكرد ورزش شهروندى حذف شدند و با حذف سوالات و ويراستارى سوالات ديخر، يك بر سشنامه ع9 سوالى مورد تاييد به دست آمد. 


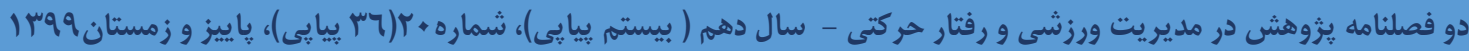

جدول شماره ع. جِارجوب نهايى مضامين بايه، سازمان دهنده و فراگير در ارزيابى عملكرد مديريت ورزش شهردارى اصفهان بر اساس الكوى سيبٍ با رويكرد ورزش شهروندى

\begin{tabular}{|c|c|c|}
\hline مضامين فراگير & مضامين سازمان & مضامين پايه \\
\hline \multirow{6}{*}{ زمينه } & نيازسنجى & 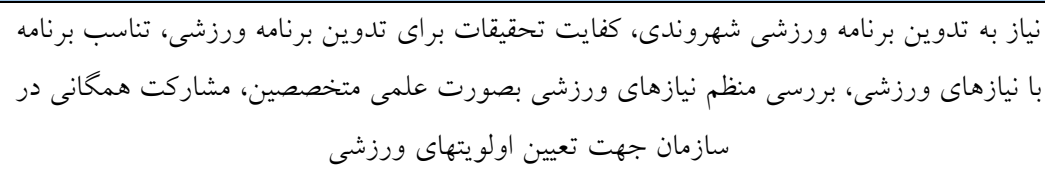 \\
\hline & اهداف & 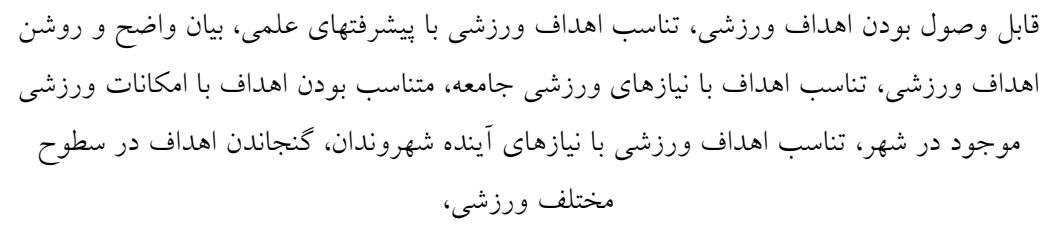 \\
\hline & عوامل فرهنگى & 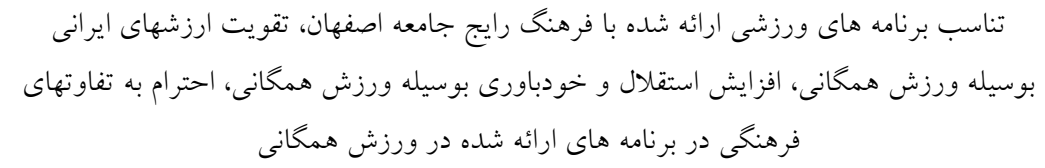 \\
\hline & عوامل اجتماعى & 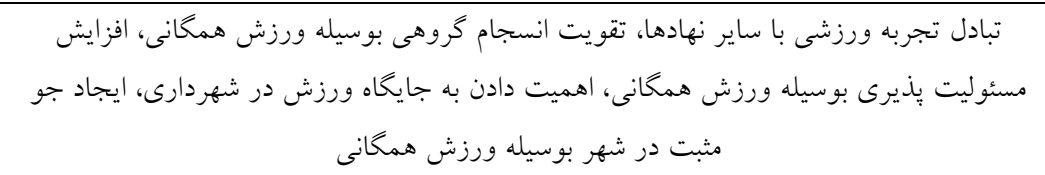 \\
\hline & عوامل اقتصادى & 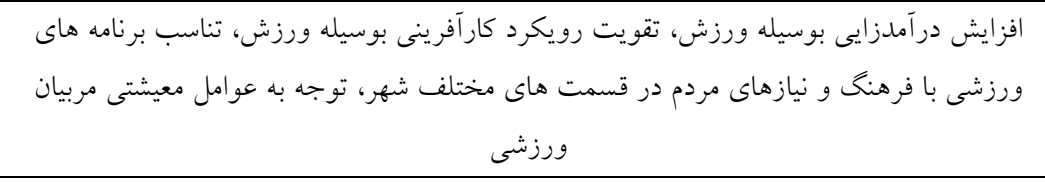 \\
\hline & قوانين و مقررات & 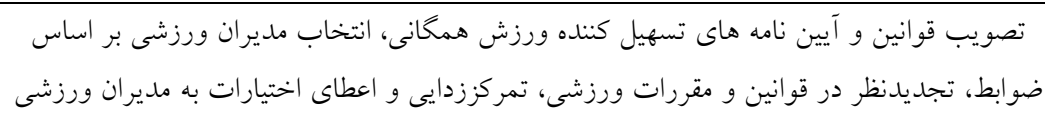 \\
\hline \multirow{4}{*}{ درونداد } & محتوا & 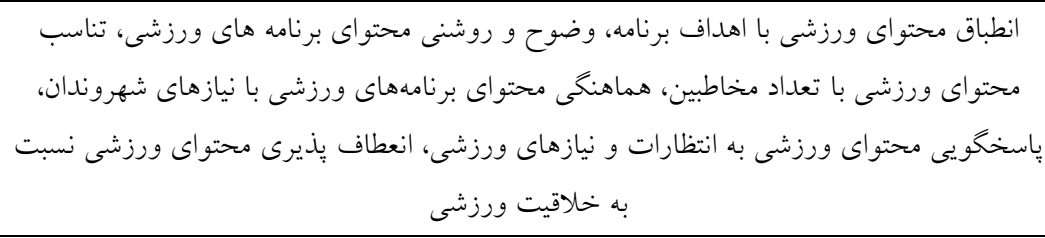 \\
\hline & منابع انسانى & استفاده از نيروى انسانى شايسته در تدوين برنامه هاى ورزشى، به كاركيرى مديران متخصص \\
\hline & منابع كالبدى & تناسب برنامه هاى ورزشى با تجهيزات و امكانات ورزشى شهردارى، افزايش امكانات رايانه اى در \\
\hline & منابع مالى & 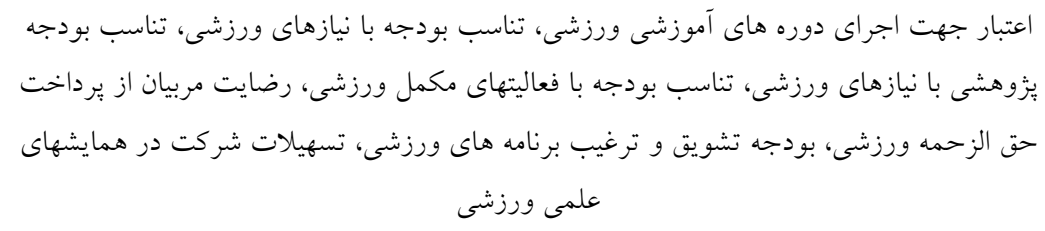 \\
\hline
\end{tabular}




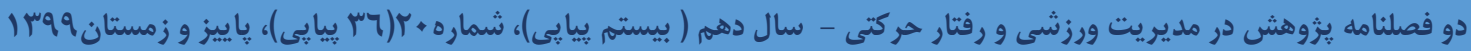

\begin{tabular}{|c|c|c|}
\hline & منابع زمانى & 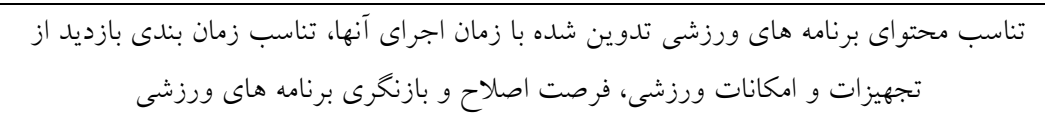 \\
\hline & منابع اطلاعاتى & 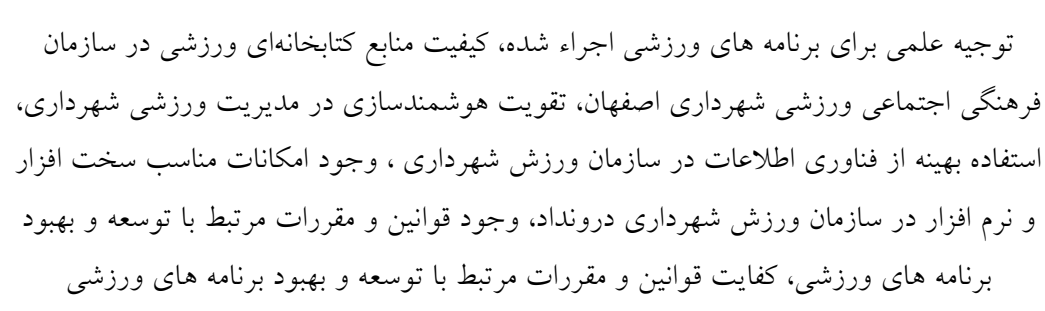 \\
\hline \multirow{5}{*}{ فر آيند } & ياددهى يادگيرى & 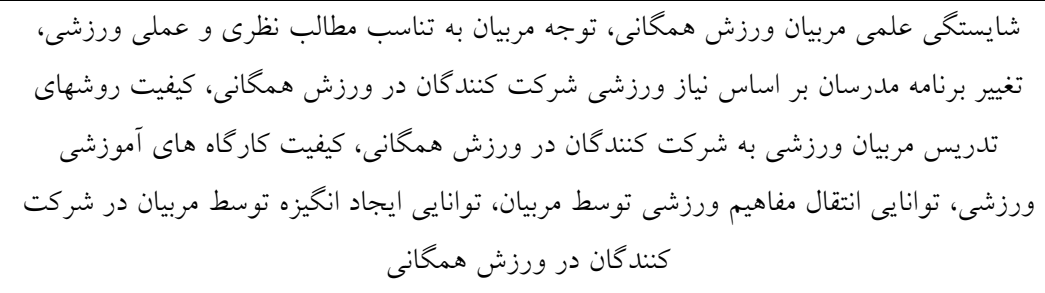 \\
\hline & نظارت & 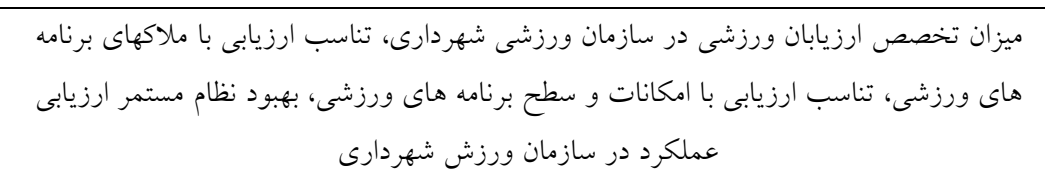 \\
\hline & فعاليتهاى مكمل & 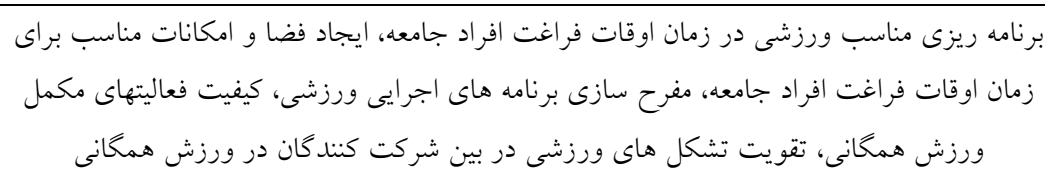 \\
\hline & نظام انخيزش & تقويت انخيزه هاى درونى مربيان ورزشى، تقويت انخيزه هاى بيرونى مربيان ورزشى، بركزارى \\
\hline & خلاقيت & 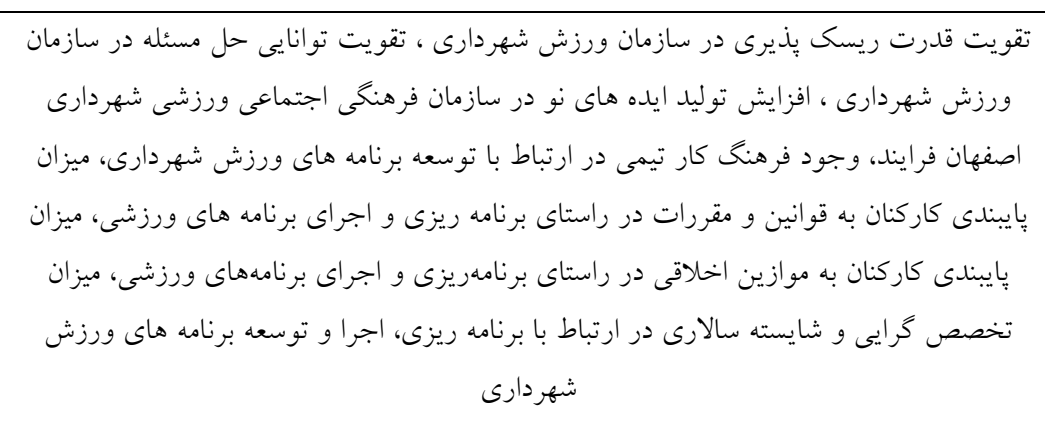 \\
\hline
\end{tabular}

https://jrsm.khu.ac.ir/ 


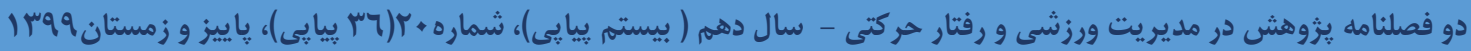

\begin{tabular}{|c|c|c|}
\hline \multirow{5}{*}{ برونداد } & 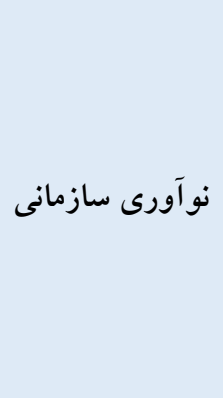 & 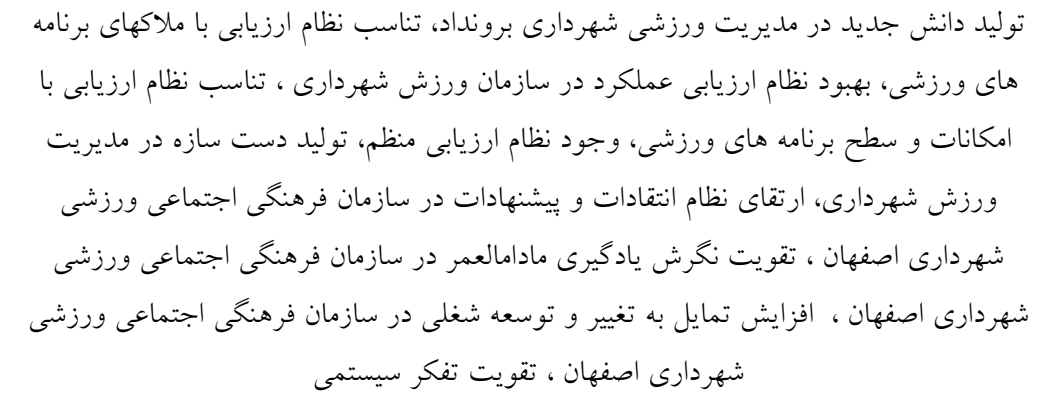 \\
\hline & 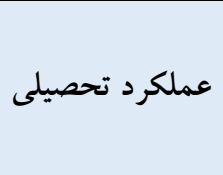 & 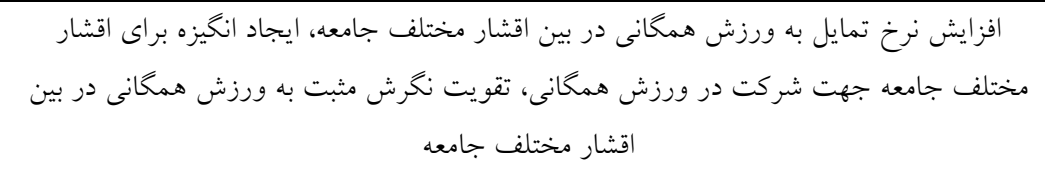 \\
\hline & ارتقاى حرفهاى & 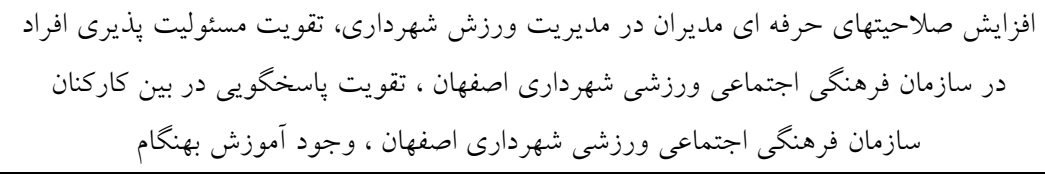 \\
\hline & توسعه مشار كت & جذب كمكهاى مردمى براى توسعه ورزش همكانى، افزايش مشاركت براى توسعه ورزش همخانى \\
\hline & سلامت روان & 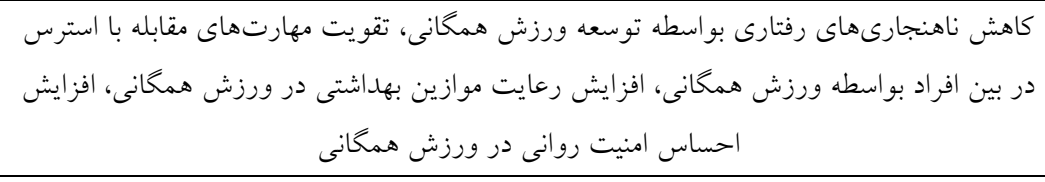 \\
\hline
\end{tabular}

جهت تجزيه و تحليل داده هاى كيفى از روش تحليل مضـمون اسـتفاده شـد، بدين صـورت كه ابتدا واحد تحليل به صورت سطر به سطر يا عبارت به عبارت بود ثبت شد (مضامين پايه)، سبس مقوله هاى ايجاد شده در مضامين پايه به صورت يك شبكه مرتبط به هم ايجاد گرديد و مضامين فراخير تدوين و درنتيجه ابزار اندازه كيرى طراحى شد. جهت دسته بندى سوالات ير سش نامه از تحليل عاملى اكتشافى استفاده شد ، كه نتايج تحليل عاملى اكتشافى صورت كرفته در جداول (0) و (7) ارائه شد.

جدول (0)، مقدار ويزه، درصد واريانس و درصد تراكمى عاملهاى باقيمانده در تحليل (عامل هايى كه داراى مقدار ويزه بزر كتر يا مساوى ا بودند) را يس از جرخش واريماكس نشان مى دهد. جدول 0. مقادير ارزش ويزه، درصد واريانس و درصد واريانس تراكمى عامل هاى استخراج شده ونه

\begin{tabular}{|c|c|c|c|c|c|c|}
\hline \multicolumn{3}{|c|}{ مجموع مجذورات بعد از جرخش واريماكس } & \multicolumn{3}{|c|}{ مقادير ويزه } & \multirow{2}{*}{ 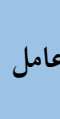 } \\
\hline درصد تراكمى & درصد واريانس & مقدار ويزه & درصد تراكمى & درصد واريانس & مقدار ويزه & \\
\hline $19 / 29$ & 19/६9 & IV/ar & $r V / 09$ & $r V / 0 q$ & ro/rq & 1 \\
\hline $\mathrm{rV} / \mathrm{VY}$ & $M / Y r$ & $17 / V V$ & $\varepsilon 9 / 0 \wedge$ & $1 / / 91$ & $\mid V / \varepsilon 7$ & $r$ \\
\hline $01 / \% 9$ & $1 \% / 07$ & $\mid Y / \varepsilon \wedge$ & $O V / \varepsilon \Lambda$ & $1 . / 9$. & $1 . / \cdot r$ & $r$ \\
\hline $7 \varepsilon / \Gamma$. & $1 r / .1$ & $11 / 9 V$ & $7 \varepsilon / \pi$. & $T / A r$ & $T / Y V$ & $\varepsilon$ \\
\hline
\end{tabular}




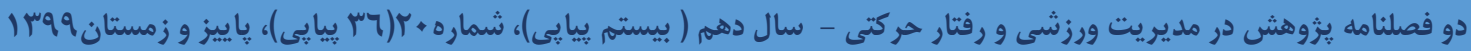

آنخونه كه در جدول (0) ديده مى شود، ارزشهاى ويزه ع عامل بزركتر از يك است و در صد يو شش واريانس مشترى بين كويهها براى اين ع عامل بر روى هم • ب/ع در صد كل واريانس متغيرها را تبيين مى كند. به عبارت ديخر، جنانجه از

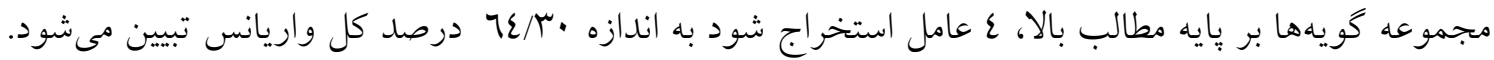
جدول7 . ترتيب سوالات يرسشنامه مربوط به ارزيابى عملكرد سازمان فرهنگى اجتماعى ورزشى شهردارى اصفهان بعد از انجام

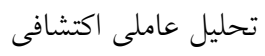

\begin{tabular}{|c|c|c|}
\hline شاخصها & مولفه & ير برسنامه \\
\hline كويه هاى ع V-V & عوامل بروندادى & عوامل عملكرد مديريت \\
\hline 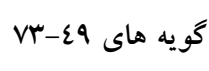 & عوامل فرآيندى & ورزش شهردارى اصفهان \\
\hline گويه هاى \ץ-1^ & عوامل دروندادى & با رويكرد (CI PP) \\
\hline كويه هاى 1-10 & عوامل زمينهاى & ورزش شهروندى \\
\hline
\end{tabular}

بر اساس نتايج جدول شماره (7) ، ترتيب سوالات يرسشنامه مربوط به ارزيابى عملكرد سازمان فرهنخى اجتماعى : بـى ورز شى شهردارى اصفهان بعد از انجام تحليل عاملى اكتشافى در خصوص عوامل زمينه اى، عوامل دروندادى، عوامل فر ايندى و عوامل بروندادى به دست آمد. با توجه به مقدار آزمون كولموكروف و ســطح معنادارى بزركتر از ه • ••، فرض صــفر مبنى بر نرمال بودن كليه مؤلفههاى

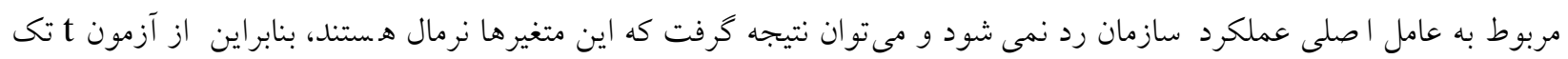

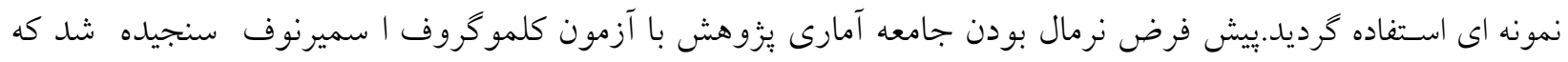
نتايج آن در جدول شماره (V) ارائه خرديد.

\begin{tabular}{|c|c|c|}
\hline \multicolumn{2}{|c|}{ كولموگروف - اسميرنوف } & \multirow{2}{*}{ متغير ها } \\
\hline سطح معنادارى & آماره & \\
\hline.$/ .0 \varepsilon$ & $\cdot / Y 17$ & عوامل زمينه اي \\
\hline$\cdot / r \cdot$ & $\cdot 1 \cdot 71$ & عوامل درونداد \\
\hline$\cdot / r \cdot$ & .1 .09 & عوامل فر آيند \\
\hline$\bullet / 1 r$. &.$/ 111$ & عوامل برونداد \\
\hline$\cdot /|\varepsilon|$ & $\cdot / 1 \cdot 0$ & عملكرد مديريت \\
\hline
\end{tabular}

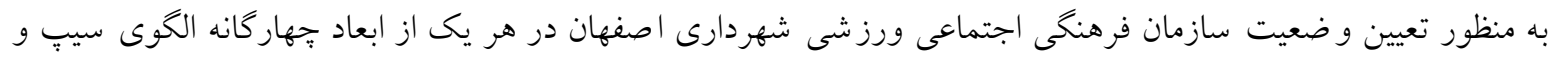

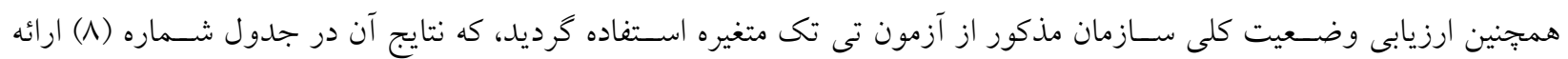




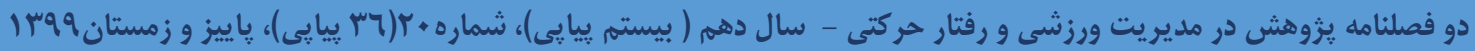

جدول ^. ارزيابى وضعيت سازمان فرهنگى اجتماعى ورزشى شهردارى اصفهان بر اساس الكوى سيب

\begin{tabular}{|c|c|c|c|c|c|}
\hline \multicolumn{5}{|c|}{ مقدار آزمون=r } & \multirow{2}{*}{ متغير ها } \\
\hline سطح معنادارى & اختلاف ميانخين از عدد r & آزمون t & انحراف استاندارد خطا & ميانكين & \\
\hline$\% \cdot 7$ & . Irr & $r / A Y q$ & $\cdot / \cdot \varepsilon 7$ & $r / \mu r$ & عوامل زمينه اي \\
\hline$\cdot 1 \cdots 9$ & $\cdot / T r \varepsilon$ & $r / 7 \vee \wedge$ & $\cdot / \cdot \varepsilon V$ & $r / 1 \varepsilon$ & عوامل درونداد \\
\hline$\cdot 1 \cdot \cdot 1$ & P/r & $r / \varepsilon 97$ & $\cdot / \cdot 71$ & $r / r_{1}$ & عوامل فر آيند \\
\hline$\% \cdots$ & . /orr & $9 / 7 \varepsilon 1$ & .1 .00 & r/or & عوامل برونداد \\
\hline$\% \cdots$ & $\cdot /$ Y07 & V/rרY & $/ \cdot r \varepsilon$ & $r / r_{O}$ & عملكرد مديريت \\
\hline
\end{tabular}

با تو جه به نتايج جدول (^)، براى مؤلفه عوامل زمينهاى با تو جه به مقدار ميانخين آن برابر با سا/س و اختلاف

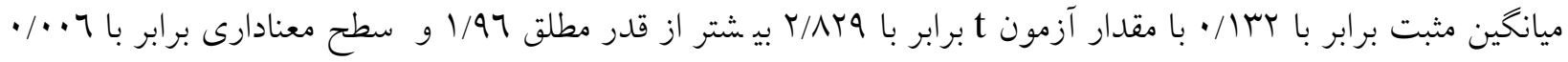
كمتر از ه • • مى توان جنين نتيجه كرفت كه عملكرد سـازمان فرهنكى اجتماعى ورزشسى شهردارى اصسفهان در حوزه ورزش شهروندى در حوزه عوامل زمينه ای در حد متوسط رو به مطلوب مىباشد جون ميانخين اين مؤلفه بالاتر از حد متوسط برابر با م مىباشد.

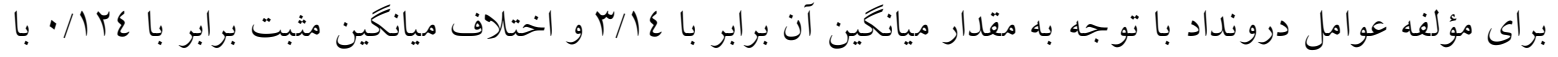

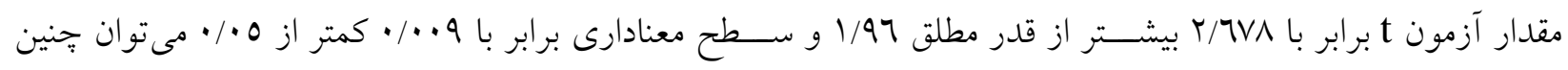
نتيجه كرفت كه عملكرد سازمان ورزش شهردارى اصفهان در حوزه ورزش شهروندى در حوزه عوامل درونداد در حد متوسط رو به مطلوب مىباشد جون ميانخين اين مؤلفه بالاتر از حد متوسط برابر با م مىباشد.

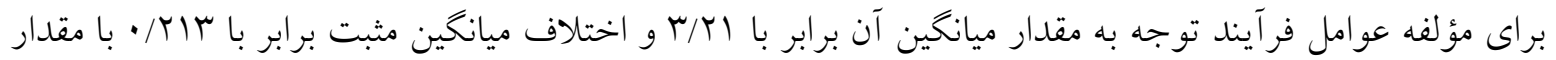

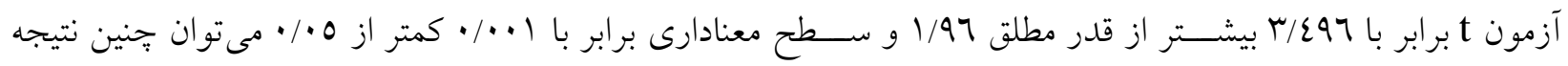
كرفت كه عملكرد سازمان ورزش شهردارى اصفهان در حوزه ورزش شهروندى در حوزه عوامل فرآيند در حد متوسط رو به مطلوب مى باشد جون ميانخين اين مؤلفه بالاتر از حد متوسط برابر با ب مىباشد.

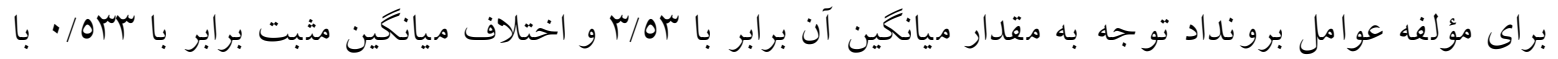

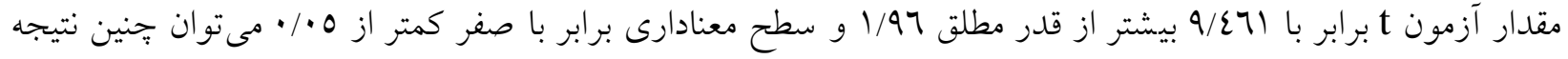
كرفت كه عملكرد سازمان ورزش شهردارى اصفهان در حوزه ورزش شهروندى در حوزه عوامل برونداد در حد مطلوب مىباشد جون ميانگين اين مؤلفه بالاتر از حد متوسط برابر با م و در تقريبا در حد ع مىباشد.

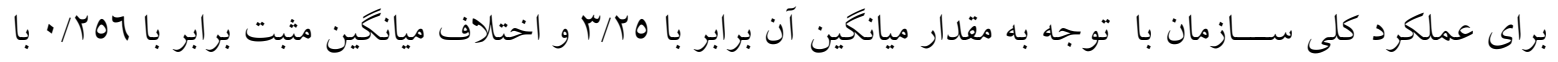

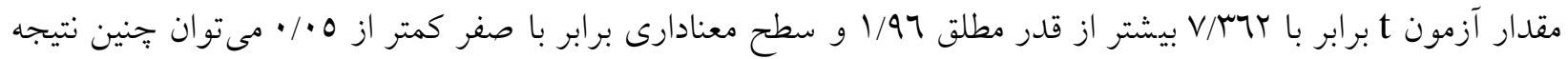




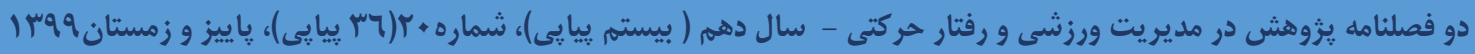

كرفت كه عملكرد سـازمان فرهنگى اجتماعى ورزشـى شـهردارى اصـفهان بر اسـاس الكوى سـيبٍ با رويكرد ورزش شهروندى در حد مطلوب رو به متوسط مىباشد جون ميانخين اين مؤلفه بالاتر از حد متوسط برابر با م مىباشد.

\section{بحث و نتيجه تيرى}

بر ا ساس مقاي سه نتايج حا صله عملكرد سازمان فرهنكى اجتماعى ورز شى شهردارى اصفهان در حوزه ورزش

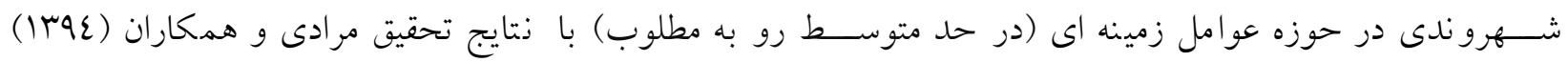

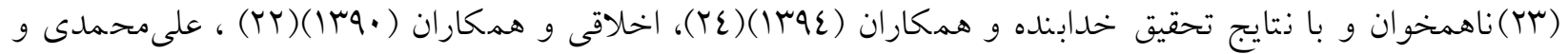

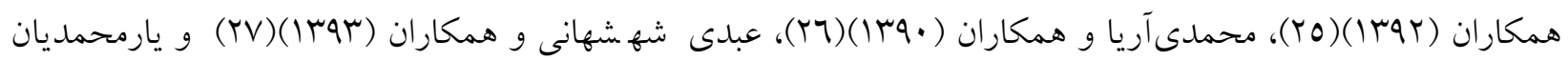

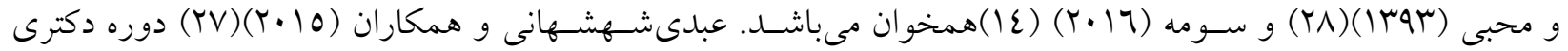
تخصصى بهداشت بارورى در ايران را در ابعاد درونداد، فرآيند و برونداد، نيمه مطلوب و در بعد زمينه، مطلوب ارزيابى

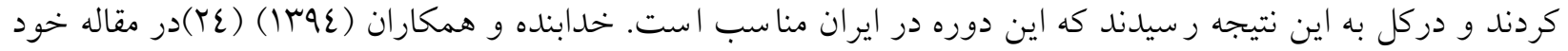
نتيجه كرفتند كه و ضعيت داذ شكده يز شكى كرمان از لحاظ و ضعيت زمينه، درونداد و فر آيند كاملا مطلوب و در بخش رِ

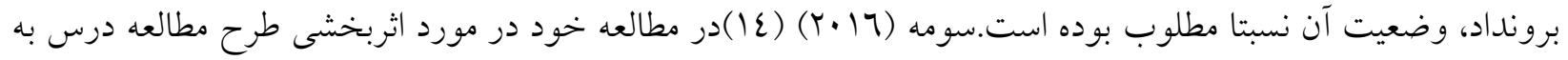
اين نتيجه ر سيدند كه اين طرح در ابعاد زمينه، درونداد، فرآيند و برونداد داراى كيفيت مطلوبى مىبا شد.با توجه به اينكه در ارزيابى زمينه به ارزيابى نيازها، علايق و مســائل محيطى مى يردازد، به اين ترتيب نيازها، مشـــلات، دارايى ها و فر صت ها به صورت گ گسترده در يك محيط ارزيابى مى گردد. ارزيابى زمينه ممكن ا ست قبل، در طول و حتى بعد از اجراى برنامه انجام شود. اخر سازمان ها، ارزيابى زمينه راقبل از برنامه انجام دهند، ارز شيابى را با مطالعه اى با قلمروى محدود در نظر گرفته اند. هنگامى كه سازمان ها ارزيابى را در طى يا بعد از برنامه به كار برند ارزيابى زمينه در تركيب با درون داد، فرآيند و برون داد تفسير مى شود. هدف اصلى اين ارزيابى فراهم سازى اطلاعات مورد نياز براى برنامه ريزى است. محور اساسى اقدامات و فعاليت ها در اينجا بررسى نيازها يا نياز سنجى است. با توجه به نتايج متوسط رو به مطلوب تحقيق در حوزه عوامل زمينه اى ، مى بايست تدوين برنامه هاى ورزشى براساس

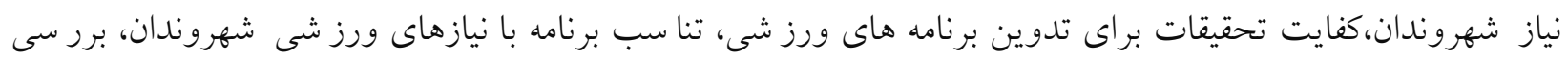
منظم نيازهاى ورزشسى بصـورت علمى توسـط متخصـصـين، مشـاركت همشانى در سـازمان جهت تعيين اولويت هاى ورزشى، قابل وصول بودن اهداف ورزشى، تناسب اهداف ورزشى با ييشرفت هاى علمى آينده شهروندان، بيان واضح و رو شن اهداف با نيازهاى ورز شى جامعه، متناسب بودن اهداف با امكانات ورزشى موجود در شهر، كنجاندن اهداف در سطوح مختلف ورزشى، تناسب برنامه هاى ورزشى ارائه شده با فرهنگ رايج جامعه اصفهان، تقويت ارزشهاى فرهنگ ايرانى بوسـيله ورزش همخانى در مناطق مختلف شـهرى، افزايش اسـتقلال و خودباورى بوسـيله ورزش همخانى، تبادل تجربه ورز شى با ساير نهادها، تقويت انسجام گروهى بو سيله ورزش همخانى، افزايش مسئوليت بذيرى بو سيله ورزش

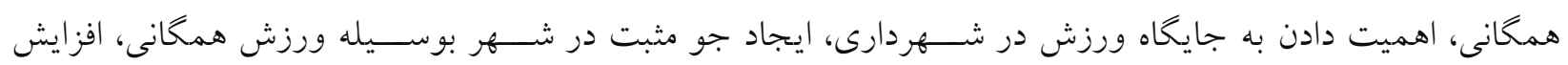




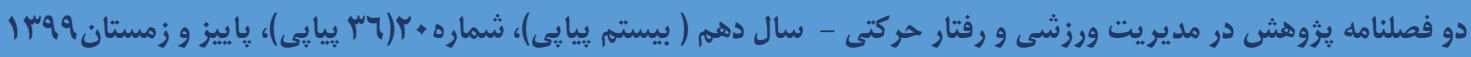

درآمدزايى بوسـيله ورزش، تقويت رويكرد كارآفرينى بوسـيله ورزش، توجه لازم به عوامل معيشـتى مربيان ورزشـى، تصويب قوانين و آيين نامه هاى تسهيل كننده ورزش همشانى، انتخاب مديران ورزشى بر اساس ضوابط و تمركززدايى و اعطاى اختيارات به مديران ورزشى رادر سطوح ايجاد ماموريت اصلى حوزه مديريت ورزش شهردارى تدوين نمود و برنامه ريزى استراتزيك جهت ر سيدن به و ضعييت بـسيار مطلوب عملكردى را ايجاد نموده تا بتوان بر اساس سنجش شاخص هاى از بيش تدوين شده، توسعه ورزش شهروندى را تحقق بخشيد. بر ا ساس مقاي سه نتايج حا صله عملكرد سازمان فرهنخى اجتماعى ورز شى شهردارى اصفهان در حوزه ورزش

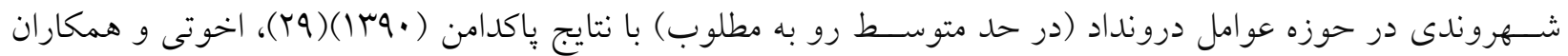

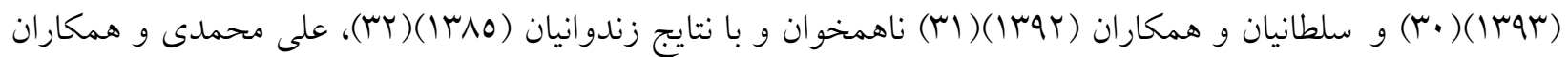

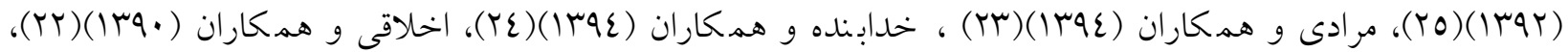

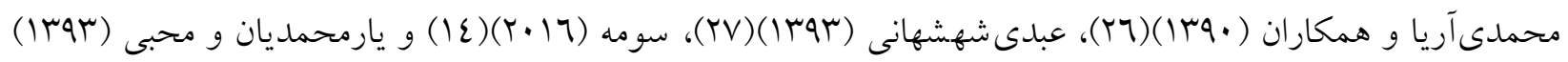

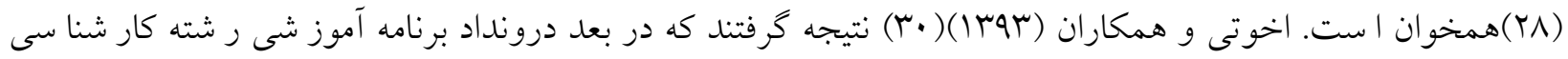
ارشد مديريت خدمات بهداشتى و درمانى وضعيت نسبتا مطلوب دارد و با وضعيت كاملا مطلوب فاصله دارد كه احتمالا دليل ناهمخوان بودن در نتايج تحقيقات با نتيجه اين تحقيق در متفاوت بودن جامعه و نمونه آمارى مى باشــــ( •ـ). مرادى(سوسا) در بزوهشى به ارزشيابى اثربخشى دوره هاى آموزش ضمن خدمت شركت ملى كاز ايران بر اساس سه

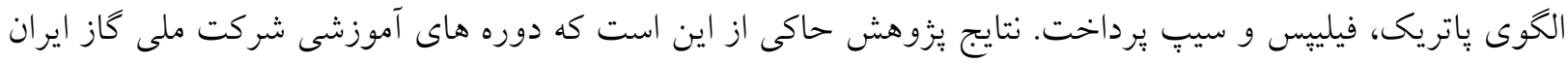
در عامل هاى واكنش، ياد گيرى، رفتار، نتايج، زمينه، فرايند و برونداد فاقد اثربخشسى لازم بوده و فقط در دو عامل

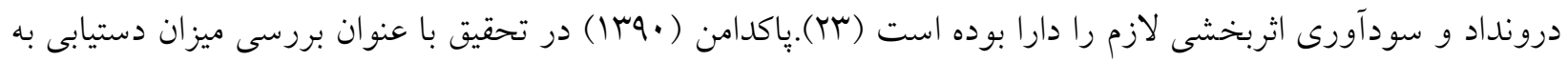
اهداف آموزشى كروههاى آموزشى بريودانتيكس و سلامت دهان بر اساس الكوى ارزشيابى سيبٍ. ارزيابى ميزان دستيابى به اهداف آموز شى دو گروه سلامت دهان و يريودنتولوزى با استفاده از الكوى سيبٍ ذشان داد كه در دو حيطه محتوا و فرآيند بين دو گروه آموزشى تفاوت آمارى معنى ارارى وجود دارد. بازنخرى عناوين فرعى در حيطههاى مذكور كه ميزان

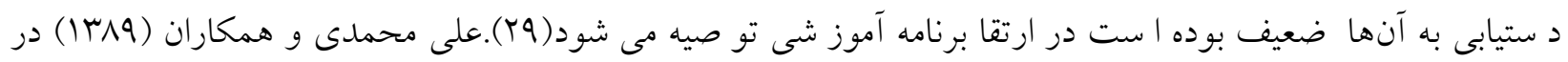
نتايج تحقيق خود نشـان داد از ديدكاه شــركت كنندكان در يزوهش وضـعيت زمينه، درونداد، فرآيند و كليت دانشـكده يز شكى كاملاً مطلوب و برونداد داذشكده ذسبتاً مطلوب مىبا شد(TO).با توجه به اينكه هدف از ارزيابى درون داد برنامه

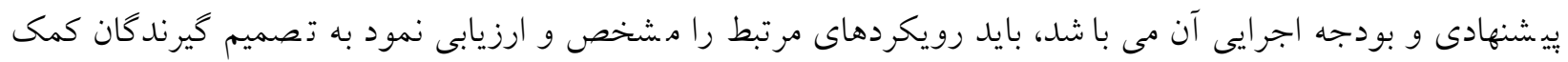
كند تا رويكردى مناسب را براى اقدام انتخاب كنند. با توجه به نتايج متوسـط رو به مطلوب تحقيق در حوزه عوامل درونداد، مى بايسـت انطباق محتواى ورزشسى با اهداف برنامه، وضسوح و روشــى محتواى برنامه هاى ورزشىى، تناسـب محتواى ورزشسى با تعداد مخاطبين، هماهنكى محتواى برنامه هاى ورز شى با نيازهاى شهروندان، انعطاف يذيرى محتواى ورز شى ذ سبت به خلاقيت ورز شى، تعديل مديران 


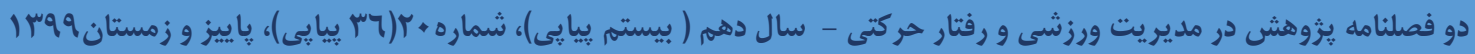

ورزشى بى صلاحيت، تناسب برنامه هاى ورزشى با تجهيزات و امكانات ورزشى شهردارى، افزايش امكانات رايانه اى در سازمان ورزش شهردارى، تقويت امكانات و فضاى ورز شى تفريحى شهر، اعتبار جهت اجراى دوره هاى آموز شى ورزشى، تناسب بودجه با نيازهاى ورزشى، تناسب بين بودجه يزوهشى با نيازهاى ورزشى، تناسب بودجه با فعاليت هاى مكمل ورزشى، رضايت مربيان از برداخت حق الزحمه ورزشى، بودجه تشويق و ترغيب برنامه هاى ورزشى، تسهيلات شركت در همايش هاى علمى ورزشى، تناسب محتواى برنامه هاى ورزشى تدوين شده با زمان اجراى آنها، تناسب زمان بندى بازديد از تجهيزات و امكانات ورز شى، فر صت اصلاح و بازنخرى برنامه هاى ورز شى، توجيه علمى براى برنامه

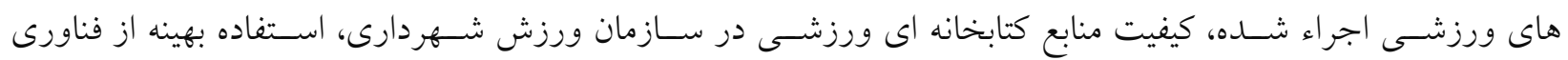
اطلاعات در سازمان فرهنكى اجتماعى ورز شى شهردارى اصفهان ، وجود امكانات مناسب سخت افزار و نرم افزار در سازمان را با علم محور نمودن فعاليت هاى مربوطه در حوزه سازمان فرهنكى اجتماعى ورزشى شهردارى اصفهان ارتقاء عملكردى ايجاد نموده و راهبردهاى كاربردى را بياده سازى نمود. بر اساس مقايسه نتايج حاصله عملكرد سازمان فرهنكى اجتماعى ورزشى شهردارى اصفهان در حوزه ورزش شهروندى

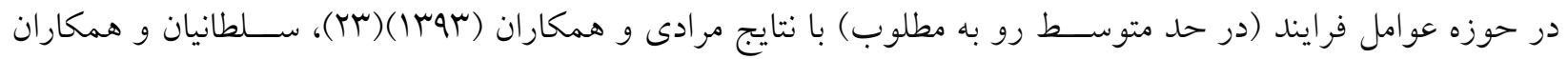

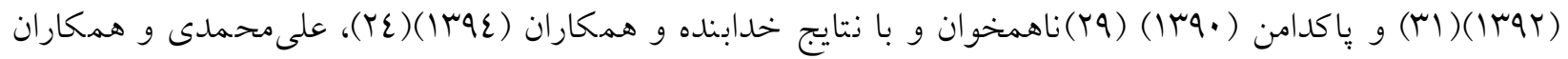

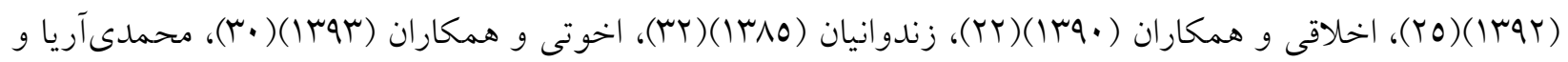

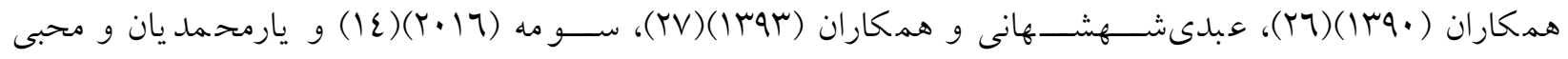

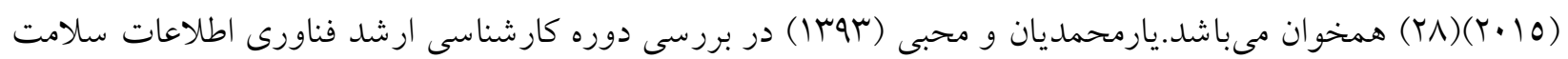
در دانشخاههاى علوم يزشكى نشان دادند كه ابعاد زمينه، ورودى، فرآيند و خروجى اين دوره در وضعيت نسبتا قابل قبول قرار دارد(Y^). اخلاقى و همكاران (•وسا) نتيجه كرفتند در بخش عوامل زمينهاى، درونداد، فرآيند و برونداد، كيفيت برنامهاى آموزشسى در آموزش عالى، در وضـعيت نسـبتا مطلوب قرار داشـتـ(Y (Y). ارزيابى فرآيند به كنترل و ارزيابى

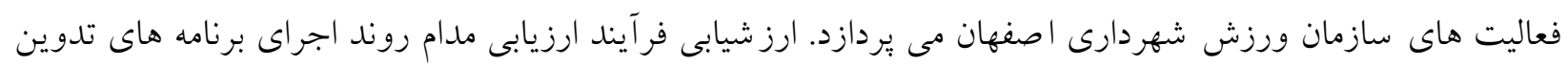
شده ورزش شهروندى مى باشد و به علاوه تغييراتى در طرح ريزى برنامه هاى تدوين شده انجام مى دهد. اين تغييرات از جمله شامل حذف فعاليت هايى است كه ضعيف اجرا مى شوند. با توجه به اينكه هدف اصلى ارزيابى فرآيند فراهم سـازى اطلاعات لازم درباره روش ها و اجراى برنامه هاى تدوين شـده سـازمان فرهنخى اجتماعى ورزشسى شهـردارى اصفهان مى باشد بدين سبب براى اتخاد تصميمات لازم است. با توجه به نتايج متوســط رو به مطلوب تحقيق در حوزه عوامل فرايند، مى بايســت شـايســـى علمى مربيان ورزش

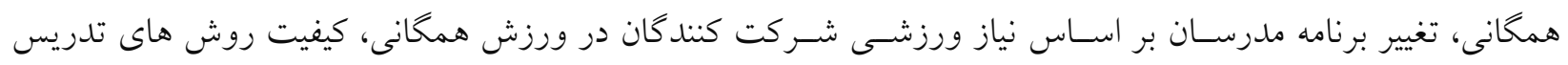
مربيان ورز شى به شركت كنند كان در ورزش همخانى، كيفيت كاركاه هاى آموز شى ورز شى، بكاركيرى نيروى اذسانى شايدسته در تدوين برنامه هاى ورز شى، به كارگيرى مديران شايدسته در سطوح مختلف سازمانى، توانايى ايجاد انخيزه 


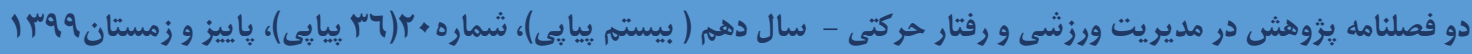

تو سط مربيان در شركت كنندكان در ورزش همگانى، ميزان تخصص ارزيابان ورز شى در مديريت ورز شى شهردارى، تناسب ارزيابى با ملاكهاى برنامه هاى ورزشى، تناسب ارزيابى با امكانات و سطح برنامه هاى ورزشى، بهبود نظام مستمر ارزيابى عملكرد در مديريت ورز شى شهردارى، برنامه ريزى مناسب ورز شى در زمان اوقات فراغت افراد جامعه، ايجاد فضا و امكانات منا سب براى زمان اوقات فراغت افراد جامعه، مفرح سازى برنامه هاى اجر ايى ورز شى، كيفيت فعاليت هاى مكمل ورزش همكانى، تقويت تشكل هاى ورزشى در بين شركت كند گان در ورزش همگانى، تقويت انخيزه هاى درونى مربيان ورز شى، تقويت انخيزه هاى بيرونى مربيان ورز شى، بركزارى كنفرانس ها و كار كاه هاى ورز شى، تقويت قدرت ريسكى يذيرى در مديريت ورزشى شهردارى، تقويت توانايى حل مسئله در مديريت ورزشى شهردارى، افزايش توليد ايده هاى نو در مديريت ورزشـى شــهردارى، وجود فرهنگ كار تيمى در ارتباط با توســعه برنامه هاى ورزش شــهردارى، ميزان بِيبندى كاركنان به قوانين و مقررات در راســتاى برنامه ريزى و اجراى برنامه هاى ورزشــى، ميزان هايبندى كاركنان به موازين اخلاقى در راسـتاى برنامه ريزى و اجراى برنامه هاى ورزشى را با تدوين و تصـويب فرايند هاى نظارتى و ايجاد آيين نامه هاى مربوطه وضعيت رو به رشدى را متصور نمود. بر اساس مقايسه نتايج حاصله عملكرد سازمان فرهنكى اجتماعى ورزشى شهردارى اصفهان در حوزه ورزش شهروندى در حوزه عوامل برونداد (در حد متو سط رو به مطلوب ) با نتايج مرادى و همكاران (سوس()(Y) و سلطانيان و همكاران

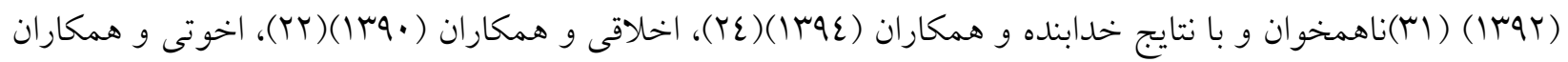

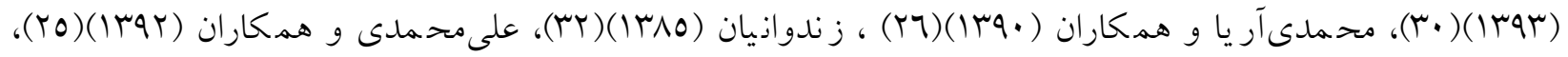

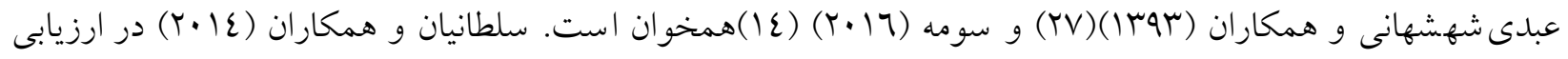
طرح شهاب ( شنا سايى و هدايت ا ستعدادهاى برتر دبير ستان) برا ساس مدل سيب نتيجه كرفتند كه اين طرح ازلحاظ اهميت در سـطح بالايى قرار دارد ولى در بعد ورودىهاى خود و عناصـرى مانند اسـتراتزىها، امكانات، راهنمايىها و مشـاورهها داراى ضـفف مى باشـــ و از وضـعيت مطلوب فاصسله دارد و در ابعاد فر آيند (مانند نظارت و كنترل طرح) و محصـول (ميزان موفقيت اين طرح) در وضـعيت متوسط قرار داردو فاصسله زيادى تا حد مطلوب دارند(اس).خدابنده و همكاران (ع (1) در مقاله خود نتيجه كرفتند كه وضسعيت دانشـكده يزشـكى كرمان از لحاظ وضـعيت زمينه، درونداد و فر آيند كاملا مطلوب و در بخش برونداد، وضعيت آن نسبتا مطلوب بوده است(عץ).ارزيابى برون داد به ارزيابى برنامه ها مى يردازد. و هدف اسـاسـى آن معين كردن ميزانى اســت كه نيازهاى همه ى ذينفعان حقيقى مورد ارزيابى واقعى قرار كرفته است و از سوى ديخر، به تفسير ارزش و شايستكى نتايج مى بردازد (سب). بازخورد در مورد برنامه هم در طول و هم بعد از اجراى برنامه لازم است. نقش ارزيابى برون داد اين است كه تعيين كند به جهه ميزان اهداف برنامه تحقق يافته است. لذا رعايت تمامى اين موارد در سازمان فرهنكى اجتماعى ورزشى شهردارى اصفهان مهم و قابل تامل است. با توجه به نتايج متوســط رو به مطلوب تحقيق در حوزه عوامل برونداد، مى بايســت توليد دانش جديد در مديريت ورز شى شهردارى، بهبود نظام ارزيابى عملكرد در مديريت ورز شى شهردارى، تناسب نظام ارزيابى با امكانات و سطح 


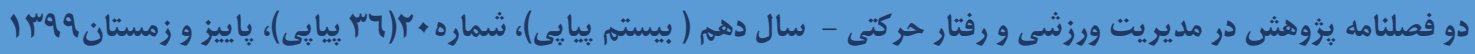

برنامه هاى ورزشى، وجود نظام ارزيابى منظم، توليد دست سازه در سازمان فرهنگى اجتماعى ورزشى شهردارى اصفهان ، ارتقاى نظام انتقادات و يمشنهادات در سازمان فرهنخى اجتماعى ورز شى شهردارى اصفهان ، تقويت نخرش يادكيرى مادام العمر در سازمان فرهنخى اجتماعى ورزشى شهردارى اصفهان ، افزايش تمايل به تغيير و تو سعه شغلى در سازمان ورزش شهردارى، تقويت تفكر سيستمى در سازمان فرهنكى اجتماعى ورزشى شهردارى اصفهان ، افزايش نرخ تمايل به ورزش همخانى در بين اقشار مختلف جامعه، ايجاد انخيزه براى اقشار مختلف جامعه جهت شركت در ورزش همخانى، افزايش صلاحيت هاى حرفه ایى مديران در مديريت ورزش شهردارى، تقويت مسئوليت بذيرى افراد در سازمان فرهنكى اجتماعى ورز شى شهردارى اصفهان ، تقويت پإسخحويى در بين كاركنان سازمان ، وجود آموزش بهنگام در سازمان ، جذب كمك هاى مردمى براى تو سعه ورزش همخانى، افزايش مشاركت براى تو سعه ورزش همخانى، كاهش ناهنجارى هاى رفتارى بواسطه تو سعه ورزش همخانى، تقويت مهارت هاى مقابله با استرس در بين افراد بواسطه ورزش همخانى، افزايش رعايت موازين بهداشــتى در ورزش همخانى، افزايش احســاس امنيت روانى در ورزش همخانى را با توجه به ارزيابى صــورت گرفته در تحقيق مذكور تقويت نموده و در جهت رسـيدن به حد بهينه عملكردى، با ايجاد نقشــه راه ورزش شهردارى اصفهان با نخاه اصفهان 0.عا توانسته كام هاى استوار و به دور از جريانات سليقه اى مديريت شهرى برداشت.

شـــاخت كاركنان قوى و اعطاى بِداش به آنها و از اين طريق، ايجاد انخيزه براى بهبود عملكرد آنان و ســـاير كاركنان، از جمله علل اصلى ارزيابى عملكرد است. مديران بايد درك در ستى از راه هاى ارزيابى عملكرد كه مى توانند به سازمان كمك كنند، داشته باشند. دو هدف مهم ارزيابى عملكرد شامل مديريتى و تو سعهاى هستند. هدف مديريتى، ارز شيابى اعضاى سازمان ها بر مبناى مقايسه اى براى تصميمات مديريت است، مثل افزايش حقوق و ترفيعات، هدف دوم يعنى هدف تو سعه اى، به اء ضا كمك مى كند تا مهارت ها و قابليت هاى خود شان را افزايش دهند. هر شغلى به و سيله عناصر اصلى و فرعى مشخص مى شود. براى موثر بودن ارزيابى عملكرد همه عنا صر درونى نيازمند ارز شيابى هـ ستند، از اين رو در مديريت راهبردى همواره بر ارزيابى سازمانى به جاى سنجش عملكردهاى فردى تاكيد مى شود

ارزيابى عملكرد سازمان فرهنخى اجتماعى ورز شى شهردارى اصفهان از يك طرف باعث بهبود و اصلاح كيفيت برنامه ورزش شهروندى مى شود و از طرف ديخر شناسايى عوامل مدل سيب در ارزيابى عملكرد سازمان مورد مطالعه باعث مى شود تا اهميت هر يك از شاخص هاى اين مدل در بهبود كيفيت برنامه هاى ورزش شهروندى مشخص شرى شود و كيفيت برنامه از نظر زمينه، درون داد، فرايند و برون دادها بهبود يابد. در اين راستا از مهم ترين عوامل مؤثر در ارزيابى

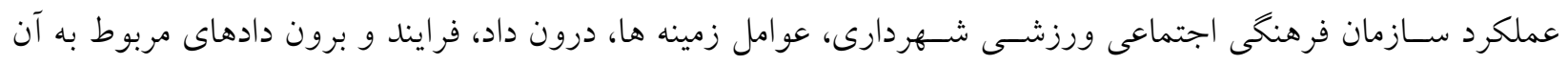
است. لذا در اين يزوهش به شناسايى اين عوامل در ارزيابى عملكرد اين سازمان برداخته شد.

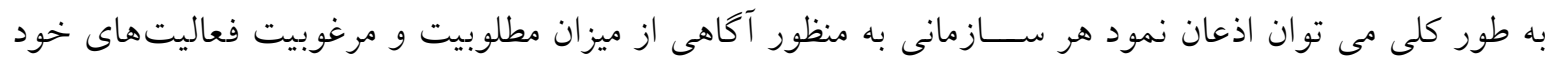




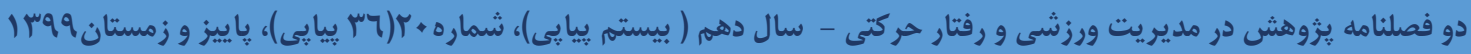

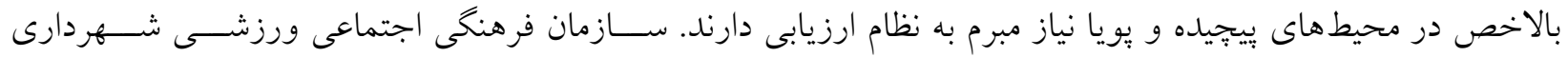
اصفهان بهعنوان بارزترين جايگاه ورزش همخانى شهر اصفهان، نقش اصلى رادر افزايش سطح سلامت اجتماعى را بر

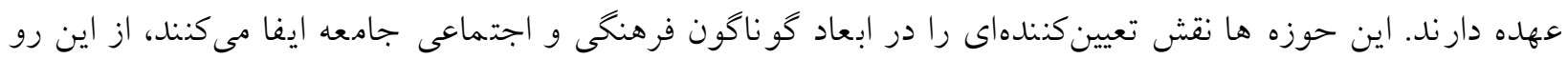
اطمينان از كيفيت مطلوب عملكرد آنها به منظور جلو گيرى از هدر رفتن بخش عمدهاى از ســـرمايههاى اجتماعى و نيز داشـتن توانايى رقابت در دنياى آينده كه در آن كيفيت مهمترين مولفه براى ادامه حيات هر ســازمان اســت، ضــرورتى انكارنايذير مىباشد.

ارزيابى عملكرد سازمان فرهنكى اجتماعى ورزشى شهردارى اصفهان هم، بهمنظور دستيابى به وضعيت موجود اين حوزه ،نخستين كام در راه تعالى سطح كيفى و كمى فعاليتهاى اين حوزه بوده است. نتايج اين مطالعه نشان داد كه اين سازمان در ابعاد زمينه، درونداد، فرآيند و برونداد در وضعيت بالاتر از متوسط و تا مطلوب ايده آل فاصله دارد، لذا توجه

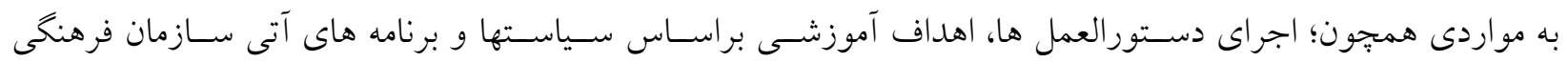
اجتماعى ورزشـى شـهردارى اصـفهان ، تعريف شــرح وظايف افراد، دانش و مهارت مورد انتظار مربيان ورزش براى عملكرد مطلوب و متناسـب با آن نيازهاى آموزش شـهروندان، وجود فهرسـتى از دانش و تخصـص هص هاى فعلى مربيان ورزش، بازنخرى سطح دانش و تخصص مورد انظظار كاركنان با توجه به تغييرات سازمانى، بركزارى دوره هاى خاص بر

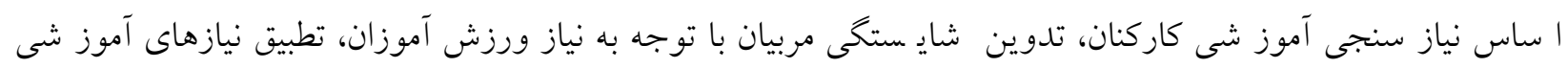
كاركنان بطور مرتب و مكرر با اهداف شغل و سازمان، توجه به راه حل ها براى كاستن فواصل مربوط به سطح تخصص

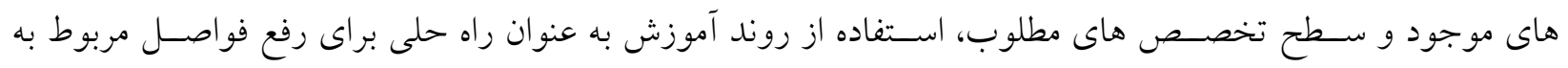
شايستكى هاى مطلوب و موجود، اطلاع رسانى به كاركنان در مورد نياز سنجى تو سط اداره منابع انسانى، همجنين توجه به الزامات قانونى سازمان در فرايند برنامه ريزى ورزش شهروندى، توجه به الزامات زمانبندى سازمان در فرايند برنامه ريزى ورزشـى، توجه به عوامل مربوط به تداركات و يشـتيبانى در فرايند برنامه ريزى ورزشسى، طراحى و برنامه ريزى ورزشى و اهداف سازمان متناسب با نيازهاى شهروندان، استفاده سازمان از اهداف، ارزيابى و انتخاب مربيان ورزشى با توجه به ويزگ گى هاى آموزشى و محدوديت هاى شناسايى شده و انتخاب نهايى كاركنان و مربيان با انعقاد قرارداد رسمى كه در آن نقش ها و مسئوليت هاى آنان در جهار بعد الكوى سيب تدوين شده است، مى تواند موثر باشئ. با توجه به ضرورت وجود اطلاعات مـ ستمر در مورد فعاليت هاى سازمان فرهنكى اجتماعى ورز شى شهردارى اصفهان ، بيششنهاد مى گردد اطلاعات مربوط به فعاليت هاى اجرا شده و در حال اجرا را به صورت مكتوب و نرمافزارى تهيه نمايند. تو صيه مى شود مديريت سازمان فرهنكى اجتماعى ورز شى شهردارى اصفهان فعاليت هاى حوزه ورزش را ابتدا به صورت آزمايشى و سيس در صورت موفقيتآميز بودن و رفع اشكالات احتمالى به صورت مستمر اين الخو را مورد استفاده قراردهد تا بتوانند بازخورد مناسب از هر ع بعد را دريافت كنند. از اين رو اتخاذ جنين رويكردى در اجراى راهبرد مديريت سازمان فرهنكى اجتماعى ورز شى شهردارى اصفهان 


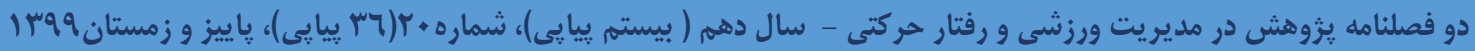

به نظر مى رسد منجر به نهادينه سازى تفكر استراتزيك در بين مديران در راستاى كار آمدى هر جّه بهتر عملكرد سازمان را فراهم آورد. از سوى ديخر جنين رويكردى كه از مدت هاى طولانى در سازمان فرهنگى اجتماعى ورزشى شهردارى اصفهان به آن احساس نياز مى شد و آن تفكرات سنتى جهت اجراى فعاليت هاى منا سبتى با هدف ارائه كزارش هاى كمى ،بدون سيا ستخذارى تو سعه ورزش شهروندى،باعث شده طى ساليان كذ شته ميلياردها اعتبار به تو سعه ورزش همگانى در شهردارى اخت صاص داده شود، اما نتيجه مطلوبى در بالا بردن سطح سلامتى اجتماعى احساس ذ شده و

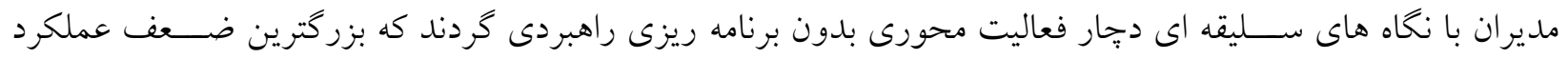
مديريت سازمان فرهنكى اجتماعى ورزشى شهردارى اصفهان مى باشد.

در نهايت موارد زير مى تواند جهت بهبود عملكرد حوزه مديريتى سـازمان فرهنكى اجتماعى ورزشسى شهـردارى اصفهان و به تبع آن سازمان هاى مربوطه در شهردارى هاى كشور ، با توجه به سياست ها و ساختار سازمانى مشابه به سازمان هدف اين يزوهش بيشنهاد كردد:

ا.در برنامه ريزى فعاليت هاى ورزش همخانى، رسـالت ، اهداف و برنامه هاى ورزش شـهـروندى با توجه به رويكرد

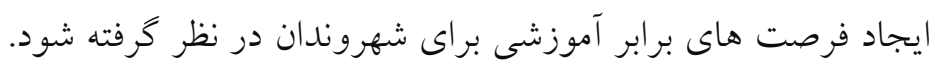
r. شرايط لازم براى ارزيابى محتواى فعاليت ها فراهم و محتواى فعاليت هاى ورزشى شهروندى بركزار شده با شرايط جهانى و تغييرات و فناورى هاى نوين همخوانى داشته باشد. س.اختصاص امكانات مالى و بودجه مناسب، زمان لازم براى اجراى فعاليت هاى ورزشى شهروندى و ابلاغ دستور العمل اجرايى برنامه هاى ورزش همخانى به طور وا ضح ، مى تواند تاثير بـسزايى در بهبود عملكرد ورزش شهروندى دا شته

ع.تو جه ويزه به حوزه ســـازمانى (آمار و اطلاعات) ، جهـت جمع آورى داده فعاليت ها تدوين شــــه ،جهـت اتخاذ تصميمات منطقى بر مبناى ارزيابى علمى و واقعى عملكرد سازمان هاى ورزشى ،صورت يذيرد.

\section{محدوديت هاى يخوهش}

1 - كمبود منابع اطلاعاتى در رابطه باوضعيت ارزيابى عملكرد مديريت ورزشى شهردارى هاى ايران و جهان r - عدم تمايل برخى از نمونه هاى مورد نظر در تحقيق براى تكميل برسشنامه

با توجه به محدوديت هاى يزوهش، يِي شنهاد مى گردد تحقيق حا ضر در شهردارى هاى كلان شهرهاى ايران در حوزه ورزش شـهـروندى انجام يذيرد و لزوم همكارى مديران و كارشـناسـان ورزش شـهردارى ها، جهت ارائه نقطه نظرات كاربردى به سبب ارتقاء علمى يزوهش هاى بعدى ، تبيين گردد. 
Sami Nia Mona. Public sports in Iran and the development of ،1-Javadipour Mohammad vision, strategy and future plans. Journal of Applied Research in Sports Management. 2013; $4: 21-30$.

2-Fathi Soroush . Sociological explanation of student sports participation. Journal of Social Sciences.2009; 4: 145-173.

3-Seyed Ameri Mir Hassan. Explain the strategies for attracting and increasing citizen participation in public and recreational sports programs. Journal of Sports Management and Science.2012; 2 (4): 23-34.

4-gholiniya javad ,Javadipour Mohammad, Farajzadeh Shahram. Honorary Flower, Inspiration. Conceptualization of public sports with the aim of citizen marketing position (goals, functions and software platforms). Journal of Communication Management in Sports Media.2007; 5: 616-629.

5-Ghofrani, Mohsen. Designing and formulating a strategy for the development of public sports in Sistan and Baluchestan province. Movement Magazine. 2009; 39:103-117

6-Ghafouri Farzad, Kargar Gholam Ali, Ghaedi Farzad. Investigating the role of championship sports on social development indicators, applied research in sports management.2016; 1: 33-44.

7. Haslip S. A treaty right to spent morduch university، Electronic of law journal.2011;1(1): 111123.

8.Saeedi Abbas . Basic concepts in physical-spatial planning. Physical-spatial planning quarter.2012 ; 3: 26-29.

9.Skolits G، Morrow J ‘Burr EM .Reconceptualizing Evaluator Roles‘American Journal of Evaluation.2009; 30(3) : 275-295.

10.Kahn K L, Mendel P, Weinberg D. Approach for conducting the longitudinal program evaluation of the US Department of Health and Human Services National Action Plan to prevent healthcare-Bachelord infections: roadmap to elimination Medical care Journal.2014; 52(3): 5962.

11.Zhang G, Zeller N, Griffith R, Metcalf D, Williams J, Shea C, \& Misulis K.. Using the context, input, process, and product evaluation model (CIPP) as a comprehensive framework to guide the planning, implementation, and assessment of service-learning programs. Journal of Higher Education Outreach and Engagement. 2011;15(4): 57-84 .

12.Ramstad E."Promoting Performance and Quality of Working LifeSimultaneously", International Journal or Productivity and PerformanceManagement.2009; 58(1):424-436.

13. Helsin P a ، \& Latham G P. The effect of upward feedback on managerial behavior، Poster session presented at the 17th annual conference of the Society of Industrial and organizational Psychological, Ontario Canada journal .2017; 8(2) : 68-80. 
14- Someh, Nasrin. Evaluating the Effectiveness of Lesson Study Plan from the Perspective of Teachers based on CIPP Model in Tehran Province. International Journal of Humanities and Cultural Studies.2016; 23(16):894-908.

15.Hj Yahya F، Jantan H Y, Saleh H, Hamdan A R. Perspective of science lecturers' in implementing science curriculum in teacher training collegeT Man in India ، Indian Journal of Science and Technology.2016;6(4) : 115-126.

16.Firharmawan H. Cipp-Based Evaluation On English For Sport Science at Sport Education Study Program Of The University Of Ma'Arif Nahdlatul Ulama .2018;24(2) : 12-18.

17- Lashkari Blokhi Mojtaba:Techniques and commands of strategic thinking. Tehran. Text publications;2010.

18- Musivand Maryam, Amrayi Mohammad, Siavashi Mohammad. Evaluation of in-service courses for physical education teachers in Hamedan province based on the CIP model. The second national conference on managing sports events. University of Hamadan.2015 ; 5 (21): 36 21.

19- Nazari Rasool. Compilation and introduction of strategic perspectives of the General Directorate of Sports and Youth of Isfahan Province through the David model. Journal of Sports Management.2014; 1: 172-157.

20-Molanzari Farzaneh, (1393). Assessing the need for the evolution of financial accounting and the operating system of Iranian universities and identifying its dimensions from the perspective of academics and experts. Journal of Experimental Accounting Research.2013; 19 (3): 79-53.

21-Habibpour Gotabi Karam. Comprehensive guide to the use of SPSS in survey research. Tehran. Publishers of thinkers ;2010.

22- Akhlaghi Faezeh, Evaluating the quality of educational programs in higher education using the Clpp model. Journal of Health Information Management. 2013; 5 (21): 629-639.

23- Moradi, Majid. Evaluating the effectiveness of in-service training courses of the National Iranian Gas Company based on the three models of Patrick, Phillips and Saip). Journal of Human Resource Management in the Oil Industry.2013; $1: 2-4$.

24- Khodabandeh Siddiqa. The relationship between work and family balance and quality of life of nurses in hospitals of Kerman University of Medical Sciences. Journal of Kerman School of Management and Medical Information.2013; 1: 46-57.

25- Ali Mohammadi Tahereh, Rezaian Mohsen, Bakhshi Hamid. Evaluation of Rafsanjan School of Medical Sciences based on Clpp theoretical model. Journal of Rafsanjan University of Medical Sciences.2010; 3: 18-12.

26- Mohammadi Aria, Kakeni Jalil. Comprehensive scientific evaluation of the Islamic Azad University of Gorgan based on the cipp model from the perspective of educational staff. Journal of Gorgan School of Nursing and Midwifery.2010; 2 :58-68.

27- Abdi Shahshahani Mahshid, Ehsanpour Soheila, yamani Niko. Design and validation of a tool 
for evaluating Iran's doctoral program based on the Cipp model. Iranian Journal of Medical Education. 2013 ;3: 252-265.

28- Yarmohammadian Mohammad Hussein, Mohebbi Noushin .Evaluation of evaluation indicators of health information technology course of master of medical universities based on cipp model. Journal of Health Education and Promotion. 2013; 4: 28-12

29- pakdaman afsaneh, Soleimani Yadollah, Kharazifard Mohammad Javad. Evaluation of educational goals of periodontics and oral health departments from the perspective of dental students of Tehran University of Medical Sciences based on CIP evaluation model. Journal of Dentistry (Tehran University of Medical Sciences). 2010; 1 : 20-25.

30- Akhoti Maryam, Yazdi Faizabadi Vahid, Begzadeh Amin, Shokohi Mustafa. Evaluation of medical services management undergraduate program of Kerman University of Medical Sciences based on cipp model in the stages of medical education. Journal of Medical Education Development Center.2014; 1: 101-113.

31- Soltanian Abbas. Evaluation of meteorite design based on cipp model components. Journal of Basic Sciences.2011; 4: 21-26.

32- Naini Prisoners Ahmad. Model-based evaluation of a comprehensive evaluation of teacher education institutions in Khuzestan province based on the SIP model, Journal of Educational Sciences and Psychology, Shahid Chamran University.2007; 2:137-142.

33.Cho $\mathrm{Y}$, Jo SJ. "Developing an Integrated Evaluation Framework for Learning", Journal of Educational Technology, 2009. 24(1):pp 694-709. 